\title{
Nitrogen uptake by phytoplankton and bacteria during an induced Phaeocystis pouchetii bloom, measured using size fractionation and flow cytometric sorting
}

\author{
P. B. Bradley ${ }^{1,7, *}$, M. P. Sanderson ${ }^{1}$, J. C. Nejstgaard ${ }^{2,3}$, A. F. Sazhin ${ }^{4}$, M. E. Frischer ${ }^{5}$, \\ L. M. Killberg-Thoreson ${ }^{1}$, P. G. Verity ${ }^{5, \mp}{ }^{,}$L. Campbell ${ }^{6}$, D. A. Bronk ${ }^{1}$ \\ ${ }^{1}$ Virginia Institute of Marine Science, The College of William \& Mary, PO Box 1346, Gloucester Point, Virginia 23062, USA \\ ${ }^{2}$ Uni Environment, Thormohlensgate 49B, 5020 Bergen, Norway \\ ${ }^{3}$ Department of Biology, University of Bergen, Thormohlensgate 53A, 5006 Bergen, Norway \\ ${ }^{4}$ P.P. Shirshov Institute of Oceanology RAS, 36 Nakhimovsky Prospect, Moscow 117997, Russia \\ ${ }^{5}$ Skidaway Institute of Oceanography, 10 Ocean Science Circle, Savannah, Georgia 31411, USA \\ ${ }^{6}$ Department of Oceanography, Texas A\&M University, College Station, Texas 77843, USA \\ ${ }^{7}$ Present address: National Oceanic and Atmospheric Administration, 1305 East West Hwy N/MB5, Silver Spring, \\ Maryland 20910, USA
}

\begin{abstract}
Uptake of inorganic and organic nitrogen $(\mathrm{N})$ by phytoplankton and bacteria was investigated during a mesocosm study conducted in Raunefjord, Norway in April 2005. One mesocosm was fertilized with nitrate and phosphate at a ratio of 16:1 and maintained in the light, while one unamended light mesocosm served as a control. Dissolved nutrients, phytoplankton and bacterial biomass, and phytoplankton community composition were monitored throughout the $26 \mathrm{~d}$ experiment. Uptake of ${ }^{15} \mathrm{~N}$-labeled ammonium and nitrate, and dual-labeled $\left({ }^{15} \mathrm{~N}\right.$ and $\left.{ }^{13} \mathrm{C}\right)$ urea and dissolved free amino acids (DFAA) was measured for phytoplankton and bacteria using 2 methods: size fractionation into $0.2-0.8$ and $>0.8 \mu \mathrm{m}$ size classes, and flow cytometric sorting based on chlorophyll autofluorescence. Prior to fertilization, dissolved inorganic N concentrations were low and comprised $~ 5 \%$ of total dissolved $\mathrm{N}$. Added nitrate was completely utilized in the amended mesocosm within $10 \mathrm{~d}$, stimulating a large bloom of colonial Phaeocystis pouchetii. Ammonium contributed over half of total measured $\mathrm{N}$ uptake by phytoplankton and bacteria in both enclosures, while nitrate and urea each supplied roughly 10 to $25 \%$. Overall, DFAA were a negligible N source to phytoplankton but contributed $11 \%$ to total bacterial $\mathrm{N}$ uptake. Bacterial uptake represented a significant portion of total uptake of all $\mathrm{N}$ forms, especially urea and DFAA. Comparison of the 2 methods for measuring phytoplankton versus bacterial uptake demonstrates how the use of $0.8 \mu \mathrm{m}$ filters can lead to significant overestimation of phytoplankton $\mathrm{N}$ uptake due to the retention of bacterial biomass.
\end{abstract}

KEY WORDS: Nitrogen uptake $\cdot$ Mesocosm experiments $\cdot$ Phaeocystis $\cdot$ Phytoplankton $\cdot$ Bacteria Flow cytometry

Resale or republication not permitted without written consent of the publisher

\section{INTRODUCTION}

Phytoplankton spring blooms typically develop once the mixed layer depth is shallow enough for photosynthetic gains to exceed respiratory losses. As such, phytoplankton biomass accumulation at high latitudes (i.e. $>45^{\circ} \mathrm{N}$ ) in the North Atlantic is initially lightlimited in spring (Townsend et al. 1992). Ultimately, however, availability of nitrate $\left(\mathrm{NO}_{3}{ }^{-}\right)$, phosphate $\left(\mathrm{PO}_{4}{ }^{3-}\right)$, and silicic acid ( $\left.\mathrm{Si}\right)$ plays an important role in determining the magnitude, duration, and composition of the spring bloom. In NE North Atlantic waters, chain- 
forming diatoms (e.g. Skeletonema spp. and Chaetoceros spp.) dominate early during the spring bloom and are generally followed by the prymnesiophyte Phaeocystis spp. (Erga \& Heimdal 1984, Lancelot \& Mathot 1987). Although the primary environmental controls on these community dynamics are unclear, some have hypothesized that the typical diatom-Phaeocystis succession of dominance is due to the competitive ability of diatoms to exploit high $\mathrm{NO}_{3}{ }^{-}$availability when $\mathrm{Si}$ concentrations exceed $2 \mu_{\mathrm{mol} \mathrm{l}} \mathrm{l}^{-1}$ (e.g. Egge \& Aksnes 1992). Others, however, have observed concurrent diatom and Phaeocystis blooms in the North Sea and argue that the latter only develop under nutrientreplete conditions once a daily irradiance threshold has been met (e.g. Peperzak et al. 1998).

These complex bloom dynamics are further complicated by the ambient nutrient regime. Human activities have increased the delivery of nitrogen $(\mathrm{N})$ and phosphorus (P) to coastal waters, but have also caused a decrease in Si loads in many regions (Humborg et al. 2000), resulting in elevated N:Si ratios. This shift toward Si limitation places diatoms at a competitive disadvantage in favor of non-siliceous phytoplankton (Conley et al. 1993). For example, over a 23 yr period in the German Bight, increasing $\mathrm{N}$ and decreasing $\mathrm{Si}$ concentrations resulted in a four-fold increase in $\mathrm{N}: \mathrm{Si}$ and a shift from diatom to flagellate (Phaeocystis spp.) dominance (Radach et al. 1990). Similarly, a relationship between abundance and duration of Phaeocystis blooms and increased nutrient loading has been suggested (Cadée \& Hegeman 2002), but others argue that eutrophication has not been a major cause of long-term variation in Phaeocystis dynamics (e.g. Gieskes et al. 2007).

Although the physiology and ecology of Phaeocystis have been studied extensively, relatively little is known about how well this alga can adapt to varying nutrient regimes during the bloom period. In late winter, $\mathrm{NO}_{3}{ }^{-}$dominates the total dissolved $\mathrm{N}$ (TDN) pool in the North Sea region and fuels the spring bloom. Diatoms tend to outcompete other algae for available $\mathrm{NO}_{3}{ }^{-}$, and can rapidly deplete the $\mathrm{NO}_{3}{ }^{-}$stock in the surface mixed layer. Phaeocystis, on the other hand, appears to benefit from a flexible $\mathrm{N}$ uptake strategy. Colonies form under $\mathrm{NO}_{3}{ }^{-}$-replete conditions, but maintain high biomass into the $\mathrm{N}$-limited early summer (Lancelot 1995). Ammonium $\left(\mathrm{NH}_{4}^{+}\right)$uptake by Phaeocystis-dominated blooms has been shown to increase either as $\mathrm{NO}_{3}{ }^{-}$concentrations decrease to low or undetectable levels (Smith 1993, Rodrigues \& Williams 2002), or as $\mathrm{NH}_{4}^{+}$concentrations increase with peak bloom biomass (e.g. Tungaraza et al. 2003). These results suggest that Phaeocystis is capable of exploiting reduced $\mathrm{N}$ forms as they become increasingly available in the late bloom stages; however, few studies have investigated the extent to which dissolved organic N (DON) can support Phaeocystis blooms. A mesocosm study similar to that presented here was conducted in 2003 and included uptake rate measurements for 2 DON substrates (urea and dissolved free amino acids [DFAA]). After depleting amended $\mathrm{NO}_{3}{ }^{-}$ stocks, the Phaeocystis-dominated assemblage relied on urea for the majority (up to $80 \%$ ) of its $\mathrm{N}$ demand as ambient concentrations of this reduced form increased (Sanderson et al. 2008).

Relative to other algae, Phaeocystis competes well for N (Riegman et al. 1992). The persistence of colonial blooms into the N-limited early summer suggests Phaeocystis either competes well against heterotrophic bacteria for limited dissolved inorganic N (DIN), or relies on alternative organic forms (e.g. urea). In theory, however, the small size and large surface area to volume ratio of heterotrophic bacteria should give them the competitive advantage over Phaeocystis. Indeed, Rodrigues \& Williams (2002) attributed up to $68 \%$ of total DIN uptake to heterotrophic bacteria during the peak Phaeocystis bloom. Mesocosm experiments in Danish coastal waters have also shown that bacteria can outcompete phytoplankton for available DIN, but required addition of labile organic carbon $\left(C_{\text {; }}\right.$ glucose) to do so (Jacquet et al. 2002, Joint et al. 2002).

Studies examining the interaction between phytoplankton and heterotrophic bacteria for shared $\mathrm{N}$ resources have suffered from inadequate methodology for quantifying their individual activities (Bronk et al. 2007, Bradley et al. 2010a). Typically, nutrient uptake by phytoplankton has been measured using glass fiber filters (e.g. Whatman GF/F, nominal pore size of $0.7 \mu \mathrm{m})$, which retain nearly all autotrophs but also 29 to $93 \%$ of the bacterial community (Lee \& Fuhrman 1987, Gasol \& Morán 1999). This same limitation applies to size fractionation as a means of measuring bacterial contribution to total uptake. Metabolic inhibitors have been used to discriminate between prokaryotic and eukaryotic activity (e.g. Veuger et al. 2004), but their lack of effectiveness and specificity limits the value of this approach (Oremland \& Capone 1988). Flow cytometric (FCM) sorting makes it possible to avoid these methodological obstacles by enabling the isolation of planktonic groups based on unique cellular properties, such as chlorophyll autofluorescence in autotrophs (e.g. Lipschultz 1995, Zubkov \& Tarran 2005).

This study represents part of a larger project designed to examine the relationship between uptake of DIN and DON by phytoplankton and heterotrophic bacteria and the expression of the genes that regulate assimilation of these $\mathrm{N}$ sources. Here we describe results from ${ }^{15} \mathrm{~N}$ uptake experiments conducted over the course of a $4 \mathrm{wk}$ mesocosm study in a coastal fjord in western Norway 
during spring 2005. The goals of this study were to (1) induce a bloom of Phaeocystis pouchetii by addition of $\mathrm{NO}_{3}{ }^{-}$and $\mathrm{PO}_{4}{ }^{3-}$, (2) compare uptake of ${ }^{15} \mathrm{~N}$-labeled DIN and DON substrates by phytoplankton and bacteria prior to and during the bloom, (3) examine dissolved nutrient availability and $\mathrm{N}$ uptake results with respect to phytoplankton community composition, and (4) compare traditional filtration with FCM sorting as a means of accurately quantifying phytoplankton $\mathrm{N}$ uptake rates. These results are compared with those from a study conducted in early spring 2003 under different initial nutrient conditions and plankton community structure, and without the use of FCM sorting to measure autotrophic N uptake (Sanderson et al. 2008).

\section{MATERIALS AND METHODS}

Mesocosm design and sampling. Experiments were conducted from 1 to 27 April 2005 in Raunefjord at the University of Bergen's Marine Biological Field Station in western Norway $\left(60^{\circ} 16^{\prime} \mathrm{N}, 05^{\circ} 14^{\prime} \mathrm{E}\right)$. Four $11 \mathrm{~m}^{3}$ enclosures (4.5 $\mathrm{m}$ deep, 2 m diameter; ANI-TEX) were suspended from a pontoon dock $200 \mathrm{~m}$ offshore. Two light mesocosms were composed of transparent polyethylene and kept open at the surface to allow penetration of $\sim 90 \%$ of photosynthetically active radiation (PAR). Two dark mesocosms were composed of black polyethylene and kept covered to prevent light penetration. Even at maximum irradiation (cloud-free day, $\sim 1450 \mu \mathrm{mol} \mathrm{s} \mathrm{s}^{-1} \mathrm{~m}^{-2}$ ), PAR inside the dark enclosures was below detection (i.e. $<0.0015 \mu \mathrm{mol} \mathrm{s}{ }^{-1} \mathrm{~m}^{-2}$ ) when measured using a LI-COR 190 quantum sensor and a LI-COR 1400 data logger.

The mesocosms were filled in situ on 1 April by pumping unfiltered fjord water from $5 \mathrm{~m}$ depth and kept well mixed throughout the experiment using a $40 \mathrm{l} \mathrm{min}^{-1}$ airlift system. To allow for new species to be introduced, avoid large shifts in $\mathrm{pH}$, and compensate for removal of sampled water, $10 \%$ of mesocosm volume was renewed daily with fjord water (3 $\mathrm{m}$ depth) using a submersible aquarium pump. Additional details about the mesocosm design are provided in Nejstgaard et al. (2006). One light (N+P) and 1 dark mesocosm were amended with $\mathrm{NaNO}_{3}$ and $\mathrm{KH}_{2} \mathrm{PO}_{4}$ at concentrations of 16 and $1 \mu \mathrm{mol} \mathrm{l} \mathrm{l}^{-1}$, respectively, after initial sampling on 1 April. Nutrients removed by the $10 \%$ water renewal were replaced daily in these 2 enclosures by adding $\mathrm{NaNO}_{3}$ and $\mathrm{KH}_{2} \mathrm{PO}_{4}$ at concentrations of 1.6 and $0.1 \mu \mathrm{mol} \mathrm{l}^{-1}$, respectively. Two other mesocosms, 1 light (Control, Ctrl) and 1 dark, were not amended and served as controls. Concentrations of chlorophyll a (chl a), $\mathrm{NO}_{\mathrm{X}}{ }^{-}\left(\mathrm{NO}_{3}{ }^{-}+\mathrm{NO}_{2}{ }^{-}\right.$, nitrite), and $\mathrm{PO}_{4}{ }^{3-}$ were measured daily in each mesocosm. Other nutrients (see 'Nutrient analysis' below), particulate $\mathrm{N}$
(PN) and particulate organic C (POC) concentrations, plankton counts, and uptake rate measurements were assayed every other day in a staggered pattern (light mesocosms: even-numbered days; dark mesocosms: odd-numbered days). Results are reported here for the light mesocosms only.

Biomass and community composition. Chl a concentrations were determined by filtering 20 to $100 \mathrm{ml}$ of sampled water, in triplicate, onto $25 \mathrm{~mm}, 0.45 \mu \mathrm{m}$ cellulose-acetate filters (Sartorius), which were then extracted in $90 \%$ acetone overnight at $4^{\circ} \mathrm{C}$ and analyzed on a Turner Design 10-AU fluorometer according to Parsons et al. (1984). Concentrations of PN and POC were measured on a Europa Geo 20/20 isotope ratio mass spectrometer equipped with an automated nitrogen and carbon analyzer for solids and liquids (ANCASL) sample processing unit, from filters used to terminate isotopic tracer experiments (see 'Uptake rate experiments' below). Phytoplankton were identified and enumerated as described in Sazhin et al. (2007). Briefly, Phaeocystis pouchetii colonies and non-motile cells within colonies were counted using both light and epifluorescence microscopy, and motile $P$. pouchetii cells and other microplankton were enumerated using epifluorescence microscopy.

Nutrient analyses. Samples for nutrient analyses were filtered through Whatman GF/F filters (precombusted at $450^{\circ} \mathrm{C}$ for $2 \mathrm{~h}$ ) and frozen immediately in either sterile polypropylene tubes $\left(\mathrm{NH}_{4}{ }^{+}\right.$and urea) or acid-washed high density polyethylene (HDPE) bottles (all others). All samples were analyzed in triplicate except urea (duplicate). Concentrations of $\mathrm{NH}_{4}{ }^{+}$and $\mathrm{PO}_{4}{ }^{3-}$ were measured on-site within $5 \mathrm{~d}$ of collection and analyzed colorimetrically using the manual phenol hypochlorite technique (Koroleff 1983) and the manual $\mathrm{PO}_{4}{ }^{3-}$ technique (Valderrama 1995), respectively. Concentrations of $\mathrm{NO}_{3}{ }^{-}, \mathrm{NO}_{2}{ }^{-}$, and $\mathrm{H}_{2} \mathrm{SiO}_{3}$ were measured at the Institute of Marine Research (Bergen) using a Skalar autoanalyzer according to Hagebø \& Rey (1984). Urea concentrations were determined using the manual monoxime method (Price \& Harrison 1987), and DFAA concentrations were analyzed as dissolved primary amines (DPA) according to the o-phthaldialdehyde method (Parsons et al. 1984). Kirchman et al. (1989) demonstrated that DFAA and DPA are approximately equal when $\mathrm{NH}_{4}{ }^{+}$concentrations are low ( $<1 \mu \mathrm{mol} \mathrm{N}{ }^{-1}$ in this case), and thus are hereafter referred to as DFAA. Concentrations of DON were determined as the difference between TDN and DIN, with TDN measured using the persulfate oxidation technique and standard deviations for mean DON values calculated using propagation of error (Bronk et al. 2000). Dissolved organic C (DOC) was measured on a Shimadzu TOC-5000 using the high-temperature combustion method (Hansell et al. 1997). 
Uptake rate experiments. Net uptake rates of ${ }^{15} \mathrm{~N}$ labeled $\mathrm{NH}_{4}{ }^{+}$and $\mathrm{NO}_{3}{ }^{-}$and dual-labeled $\left({ }^{15} \mathrm{~N},{ }^{13} \mathrm{C}\right)$ urea and DFAA (an algal extract consisting of 16 amino acids; Cambridge Isotope Laboratories) were measured for all 4 mesocosms described above. Eight 11 polyethylene bottles were filled with water from each mesocosm (4 substrates in duplicate), spiked separately with labeled substrates, and incubated for roughly $3 \mathrm{~h}$ at in situ light and temperature conditions in the fjord. Ammonium, urea, and DFAA tracers were

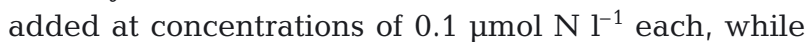
${ }^{15} \mathrm{NO}_{3}{ }^{-}$additions were between 0.4 to $0.8 \mu \mathrm{mol} \mathrm{N}{ }^{-1}$.

Incubations were terminated using filters of varying type and pore size to examine different components of the microbial community. An aliquot from each bottle (35 to $200 \mathrm{ml}$ ) was initially filtered through a $25 \mathrm{~mm}$, $0.8 \mu \mathrm{m}$ silver membrane filter; this $>0.8 \mu \mathrm{m}$ fraction represents the traditional approach to measuring phytoplankton $\mathrm{N}$ uptake. The $0.8 \mu \mathrm{m}$ filtrate was then passed through a $25 \mathrm{~mm}, 0.2 \mu \mathrm{m}$ silver filter; this $0.2-0.8 \mu \mathrm{m}$ fraction represents the bacterial size class. A separate volume of incubated sample (80 to $200 \mathrm{ml}$ ) was first screened through $35 \mu \mathrm{m}$ mesh to remove Phaeocystis pouchetii colonies and other plankton large enough to clog the flow cytometer orifice. Using $0.2 \mu \mathrm{m}$-filtered fjord water, the retained cells were then washed from the mesh onto a $25 \mathrm{~mm} \mathrm{GF/F} \mathrm{filter,}$ which was later analyzed to determine $\mathrm{N}$ uptake by the $>35 \mu \mathrm{m}$ fraction. The $<35 \mu \mathrm{m}$ filtrate was concentrated over a $47 \mathrm{~mm}, 0.2 \mu \mathrm{m}$ Supor filter to a volume of 5 to $13 \mathrm{ml}$, which was preserved with paraformaldehyde at a final concentration of $2 \%$ and frozen in liquid $\mathrm{N}$ for FCM sorting. This concentration technique was analyzed in a relatively turbid Chesapeake Bay tributary to determine how much phytoplankton biomass is lost (i.e. adsorbed) to the Supor filter. In the samples concentrated from 100-200 to $10 \mathrm{ml}$, chl a averaged 95 $\pm 3 \%$ of whole-water (unconcentrated) chl a values, whereas the Supor filter retained $3 \pm 1 \%$ of $\mathrm{chl} a$, on average (Bradley et al. 2010a).

All GF/F and silver filters were kept frozen at $-20^{\circ} \mathrm{C}$ until $1 \mathrm{~d}$ prior to analysis, then thawed and dried at $40^{\circ} \mathrm{C}$ overnight. A Europa GEO 20/20 isotope ratio mass spectrometer with an in-line ANCA-SL was used to determine PN and POC concentrations as well as ${ }^{15} \mathrm{~N}$ and ${ }^{13} \mathrm{C}$ isotopic enrichments from each sample. Both specific $\left(V, \mathrm{~h}^{-1}\right)$ and absolute $\left(\rho, \mu \mathrm{mol} \mathrm{N} \mathrm{l}^{-1} \mathrm{~h}^{-1}\right) \mathrm{N}$ uptake rates were calculated using the following equations of Dugdale \& Goering (1967):

$$
\begin{gathered}
V=\frac{\mathrm{PN}^{15} \mathrm{~N}_{\mathrm{XS}}}{\operatorname{Sub}^{15} \mathrm{~N}_{\mathrm{XS}} \times \text { time }} \\
\rho=V \times[\mathrm{PN}]
\end{gathered}
$$

where $P N{ }^{15} \mathrm{~N}_{\mathrm{XS}}$ is the 'excess' isotopic enrichment (i.e. when corrected for ${ }^{15} \mathrm{~N}$ natural abundance), Sub ${ }^{15} \mathrm{~N}_{\mathrm{XS}}$ is the corrected enrichment of the substrate pool, time is the length $(\mathrm{h})$ of the incubation, and $[\mathrm{PN}]$ is the concentration of PN in the sample at the end of the incubation. Carbon uptake rates were calculated similarly using POC ${ }^{13} \mathrm{C}_{\mathrm{XS}}$, Sub ${ }^{13} \mathrm{C}_{\mathrm{XS}}$, and [POC]. In contrast to absolute uptake rates, specific rates describe the physiological ability of cells to assimilate $\mathrm{N}$ and are not influenced by biomass (Dugdale \& Wilkerson 1986). As such, specific uptake rates are analogous to growth

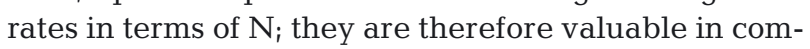
paring how different plankton fractions use a particular $\mathrm{N}$ substrate, and can also be used to examine whether $\mathrm{N}$ fertilization affects the ability of phytoplankton and bacteria to utilize $\mathrm{N}$.

To measure $\mathrm{NH}_{4}{ }^{+}$regeneration rates and correct $\mathrm{NH}_{4}{ }^{+}$uptake rates for isotope dilution, the $\mathrm{NH}_{4}{ }^{+}$pool following incubation with ${ }^{15} \mathrm{NH}_{4}{ }^{+}$was isolated using reverse-phase solid-phase extraction columns (Supelco Supelclean LC-18), and the product was analyzed for isotopic enrichment (Selmer \& Sörensson 1986, Brzezinski 1987). Regeneration rates were calculated using the Blackburn-Caperon linear differential equation model, and an exponential average for the isotopic enrichment of the $\mathrm{NH}_{4}{ }^{+}$substrate pool was calculated and used in place of Sub ${ }^{15} \mathrm{~N}_{\mathrm{XS}}$ in Eq. (1) to correct for isotope dilution (Glibert et al. 1982).

The percent of bacterial biomass retained on $0.8 \mu \mathrm{m}$ silver filters was estimated for both mesocosms to determine the phytoplankton-only (Phyto) PN. Bacterial abundance measured during this study (M. E. Frischer et al. unpubl. data) was converted to total bacterial biomass using a cellular $\mathrm{N}$ content of $12 \mathrm{fg} \mathrm{N}$ cell $^{-1}$, which was determined by Vrede et al. (2002) using bacterial isolates from Raunefjord. Bacterial biomass retained by $0.8 \mu \mathrm{m}$ filters was calculated as the difference between total bacterial biomass and 0.2 to $0.8 \mu \mathrm{m}$ PN. On average, $24 \pm 14$ and $58 \pm 21 \%$ of total bacterial biomass was retained on $0.8 \mu \mathrm{m}$ filters in the $\mathrm{Ctrl}$ and $\mathrm{N}+\mathrm{P}$, respectively. Therefore, Phyto PN was estimated from the $>0.8 \mu \mathrm{m}$ and $0.2-0.8 \mu \mathrm{m}$ PN using bacterial retention values of 25 and $50 \%$ for the Ctrl and $\mathrm{N}+\mathrm{P}$, respectively. Higher bacterial retention in the amended mesocosm was likely due to enhanced clogging of the $0.8 \mu \mathrm{m}$ filters by Phaeocystis pouchetii colonies. Furthermore, these percentages represent conservative estimates of bacterial retention based on the lower conversion factor of $12 \mathrm{fg} \mathrm{N} \mathrm{cell}^{-1}$ (for C- or Plimited cells) rather than $35 \mathrm{fg} \mathrm{N}^{\mathrm{N}} \mathrm{Cell}^{-1}$ for bacteria in exponential growth (Vrede et al. 2002).

FCM sorting of autotrophs. Concentrated samples were kept frozen at $-80^{\circ} \mathrm{C}$ and thawed at room temperature prior to sorting on a Beckman-Coulter Epics Altra flow cytometer located at the Virginia Institute of Marine 
Science and equipped with an argon ion laser operating at $488 \mathrm{~nm}$ and $250 \mathrm{~mW}$. Phytoplankton cells were discriminated based on chlorophyll autofluorescence using a $675 \mathrm{~nm}$ optical filter and sorted at rates ranging from 300 to 1200 cells s $^{-1}$. The threshold on this trigger signal was adjusted between 100 and $140 \mathrm{~V}$ to remove background noise, and autotrophs were then gated from nonfluorescent detritus, bacteria, and other particles. The waste stream was periodically collected and analyzed using epifluorescence microscopy to verify sorting accuracy. The purity of the sorted samples was assessed using bacterial enumeration by flow cytometry and acridine orange direct counts (Sherr et al. 2001); on average, $94 \pm 2 \%$ of bacteria were removed during sorting. Based on bacterial abundance from both mesocosms and a $\mathrm{N}$ content of $12 \mathrm{fg} \mathrm{N} \mathrm{cell}^{-1}$ (Vrede et al. 2002), bacterial biomass contributed $\sim 4 \%$ of Phyto PN in the final sorted sample. Sorted phytoplankton cells were then filtered onto $25 \mathrm{~mm}$ GF/F filters. Since GF/F filters retain roughly half the bacterial community, bacterial contribution to Phyto uptake measured in FCM-sorted samples is considered negligible. The filters were stored at $-20^{\circ} \mathrm{C}$ until analysis on the mass spectrometer as described above (see 'Uptake rate experiments'). A small amount of carrier (1 $\mu \mathrm{g} \mathrm{N}$ from $\left(\mathrm{NH}_{4}{ }^{+}\right)_{2} \mathrm{SO}_{4}$, and $8 \mu \mathrm{g} \mathrm{C}$ from sucrose) was added to each pelletized sample to produce total $\mathrm{N}$ masses sufficiently above the Europa's detection limit $(\sim 1 \mu \mathrm{g} \mathrm{N})$ for reliable ${ }^{15} \mathrm{~N}$ atom percent enrichment values. A mathematical carrier correction was performed when calculating the final ${ }^{15} \mathrm{~N}$ isotopic enrichment.

Potential negative effects of the sorting method on ${ }^{15} \mathrm{~N}$ tracer retention have been examined previously and are described in depth elsewhere (Bradley et al. 2010a). Briefly, uptake rates measured from FCMsorted phytoplankton were compared with those from filters exposed to boiling water to examine whether preserving, freezing, and sorting cells causes phytoplankton to lose $\mathrm{N}$ taken up but not yet assimilated. Significantly lower uptake rates in the boiled versus FCM-sorted samples confirmed that the integrity of sorted phytoplankton cells was minimally compromised, if at all, by our methodology. This conclusion agrees with previous research demonstrating that phytoplankton cellular integrity remains intact (i.e. no radioisotope was lost) in samples sorted following primary production incubations (Rivkin et al. 1986).

Statistical analyses. The significance of apparent differences in mean uptake rates between either plankton fractions or mesocosms was assessed using Student's $t$-tests. Potential relationships between measured variables (e.g. uptake rates and ambient concentrations) were evaluated for significance using Pearson's Correlation. Results of these statistical analyses are reported as $\mathrm{p}$ values and $\mathrm{r}^{2}$ correlation coefficients, where appropriate.

\section{RESULTS}

\section{Biomass and community composition}

A large phytoplankton bloom developed in the amended mesocosm (N+P), whereas phytoplankton biomass decreased in the unamended mesocosm (Ctrl) over the course of the experiment. Concentrations of chl a in N+P increased to a maximum of $32.3 \mu \mathrm{g} \mathrm{l}^{-1}$ on Day 13, then decreased rapidly over the final $2 \mathrm{wk}$ (Fig. 1A). In the Ctrl, chl a increased only slightly before declining gradually.

Trends in phytoplankton (Phyto; see 'Materials and methods') PN concentrations resembled those of chl a in that PN increased in the N+P over the first $2 \mathrm{wk}$ and decreased in the Ctrl (Fig. 1B). Unlike chl $a$, however, Phyto $\mathrm{PN}$ remained relatively high in the $\mathrm{N}+\mathrm{P}$ over the last $2 \mathrm{wk}$, which was likely due to inclusion of detrital PN. Phyto PN concentrations represented $86 \%$ of the $>0.8 \mu \mathrm{m}$ PN in both mesocosms. The $>35 \mu \mathrm{m}$ PN, which consisted of Phaeocystis pouchetii colonies, peaked at

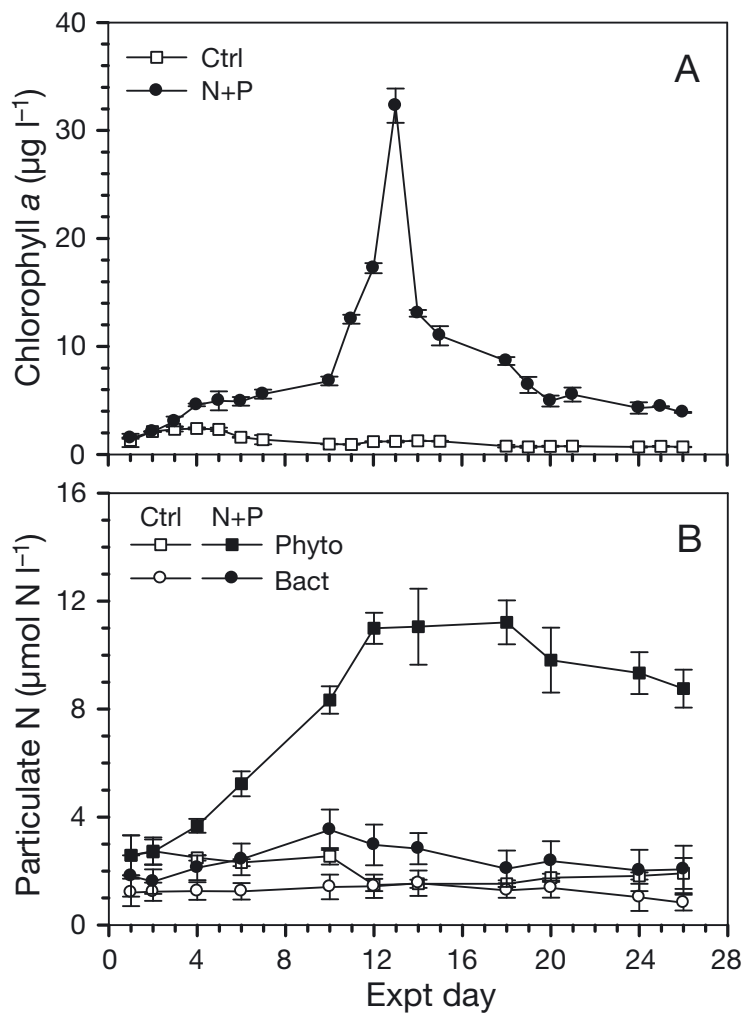

Fig. 1. Concentrations of (A) chlorophyll a and (B) phytoplankton-only (Phyto) and total bacterial (Bact) particulate $\mathrm{N}$ (PN) in control (Ctrl; open symbols) and amended $(\mathrm{N}+\mathrm{P}$; closed symbols) mesocosms. Phyto fraction = combined uptake of plankton retained on a $35 \mu \mathrm{m}$ mesh and autotrophs $(<35 \mu \mathrm{m})$ isolated using flow cytometric sorting. Bact PN corrects $0.2-0.8 \mu \mathrm{m}$ PN for bacterial biomass retained on $0.8 \mu \mathrm{m}$ filters. Error bars: $\pm 1 \mathrm{SD}$ of the mean $(\mathrm{n}=2-3)$ (smaller than symbols in some cases) 
$9.5 \mu \mathrm{mol} \mathrm{N} \mathrm{^{-1 }}$ in $\mathrm{N}+\mathrm{P}$, the only mesocosm with a colonial bloom (data not shown). The ratio of Phyto PN:chl a averaged $1.9 \pm 0.6$ and $1.4 \pm 0.6$ in the $\mathrm{Ctrl}$ and $\mathrm{N}+\mathrm{P}$, respectively (data not shown). Particulate $\mathrm{N}$ concentrations in the $0.2-0.8 \mu \mathrm{m}$ fraction were adjusted for the percent of bacterial biomass retained on $0.8 \mu \mathrm{m}$ filters (25 and $50 \%$ for the $\mathrm{Ctrl}$ and $\mathrm{N}+\mathrm{P}$, respectively; see 'Materials and methods'). Total bacterial (Bact) PN varied little in Ctrl (mean: $1.3 \pm 0.2 \mu \mathrm{mol} \mathrm{N} \mathrm{l}^{-1}$ ), but nearly doubled over the first $10 \mathrm{~d}$ in N+P (Fig. 1B).

The phytoplankton community in the Ctrl was initially dominated by solitary Phaeocystis pouchetii cells, which then gave way to other small phototrophic flagellates as well as Cyanobacteria after about $10 \mathrm{~d}$ (Fig. 2A). Diatom abundance in the Ctrl remained at relatively low levels. In the $\mathrm{N}+\mathrm{P}, P$. pouchetii dominated throughout the study and shifted from solitary motile cells during the first $10 \mathrm{~d}$ to colonial cells thereafter (Fig. 2B). Diatom abundance in the N+P was greatest during the first week, whereas cell numbers of other autotrophs (mainly flagellates) generally increased during the study. Based on microscope counts, the abundance of heterotrophic ciliates and flagellates was noticeably higher in the N+P relative to the Ctrl.

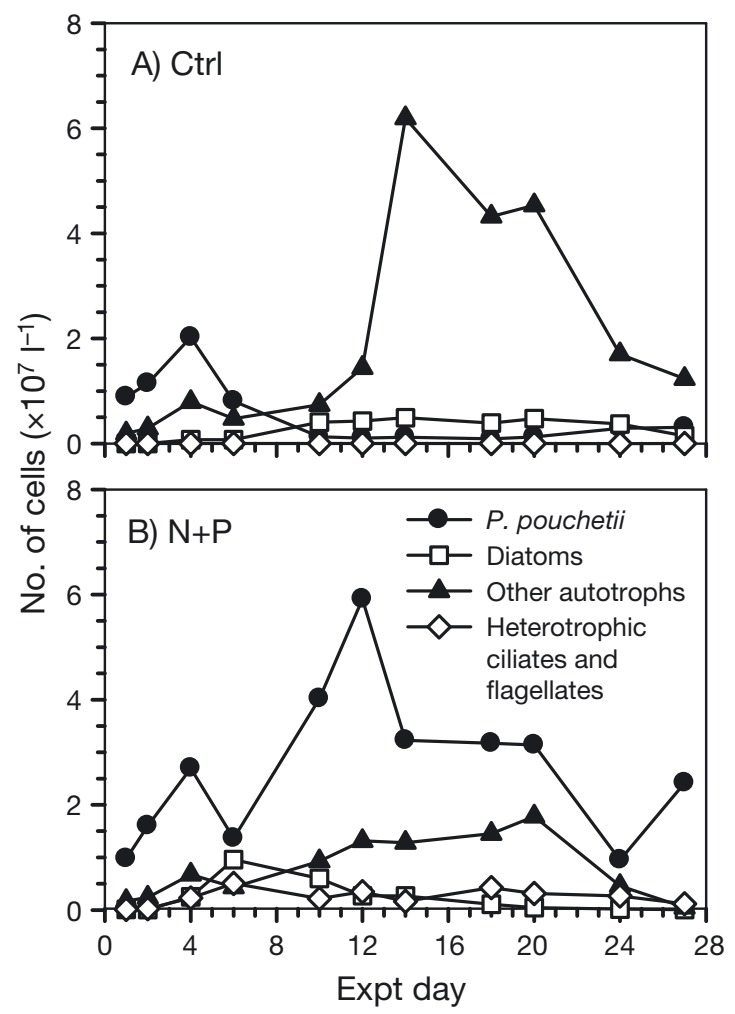

Fig. 2. Plankton community composition in numbers of cells $\left(\times 10^{7} \mathrm{l}^{-1}\right)$ in (A) control (Ctrl) and (B) nutrient-amended $(\mathrm{N}+\mathrm{P})$ mesocosms. 'Other autotrophs' fraction consisted mostly of small, phototrophic flagellates in both mesocosms and cyanobacteria in Ctrl only

\section{Nutrients}

Concentrations of TDN were 5 to $6 \mu \mathrm{mol} \mathrm{N}{ }^{-1}$ in the Ctrl (Fig. 3A). In the N+P, TDN decreased from 22 to $6 \mu \mathrm{mol} N$ $\mathrm{l}^{-1}$ within $9 \mathrm{~d}$ of fertilization (Fig. 3C). The plankton community in both mesocosms quickly removed any available $\mathrm{NO}_{3}{ }^{-}$. Nitrate concentrations were consistently low $\left(\leq 0.2 \mu \mathrm{mol} \mathrm{N}{ }^{-1}\right)$ in the Ctrl and decreased in the $\mathrm{N}+\mathrm{P}$ from 16.2 to $0.01 \mu \mathrm{mol} \mathrm{N}{ }^{-1}$ by Day 10 (Fig. 3A,C). In both mesocosms, $\mathrm{NO}_{2}^{-}$concentrations varied little and were $\leq 0.1 \mu \mathrm{mol} \mathrm{N}{ }^{-1}$, while $\mathrm{NH}_{4}^{+}$concentrations were $\leq 0.9 \mu \mathrm{mol} \mathrm{N}{ }^{-1}$ and highest during the final $2 \mathrm{wk}$ of the study (Fig. 3B,D). Excluding the first week in the $\mathrm{N}+\mathrm{P}$, when $\mathrm{NO}_{\mathrm{X}}{ }^{-}$comprised up to $73 \%$ of TDN, DIN accounted for $7 \pm 4 \%$ of TDN in both mesocosms (Table 1 ).

Differences in DON concentrations between the 2 mesocosms were relatively small (Fig. 3A,C), although the mean concentration in the N+P $\left(5.9 \pm 0.5 \mu \mathrm{mol} \mathrm{N}{ }^{-1}\right)$ was significantly higher than in the Ctrl $(5.0 \pm 0.5 \mu \mathrm{mol}$ $\mathrm{N}^{-1}$; $\left.\mathrm{p}<0.001\right)$. Urea concentrations remained steady at 0.3 to $0.6 \mu \mathrm{mol} \mathrm{N}^{-1}$, decreasing slightly in the Ctrl and increasing slightly in the N+P over the course of the experiment (Fig. 3B,D). Concentrations of DFAA were $<0.7 \mu \mathrm{mol} \mathrm{N} \mathrm{l}^{-1}$ in both mesocosms, but varied considerably. On average, urea and DFAA together comprised $11 \%$ of DON in both mesocosms (Table 1). Concentrations of DOC were fairly constant between 85 to $100 \mu \mathrm{mol} \mathrm{C} \mathrm{^{-1 }}$ in the Ctrl, but increased in the N+P to a maximum of $251.3 \mu \mathrm{mol} \mathrm{C} \mathrm{l}^{-1}$ (Fig. 4A). Consequently, ratios of DOC:DON were $\sim 15$ to 20 in the Ctrl and increased from 16 to 37 in N+P (data not shown).

Phosphate concentrations were $\leq 0.1 \mu \mathrm{mol} \mathrm{N} l^{-1}$ in the Ctrl, and amended $\mathrm{PO}_{4}{ }^{3-}$ was consumed quickly, but not completely, in the $\mathrm{N}+\mathrm{P}$ (Fig. 4B). The mean ratio of $\mathrm{N}: \mathrm{P}$ (DIN: $\mathrm{PO}_{4}{ }^{3-}$ ) in the Ctrl, excluding an outlier on Day 12, was $8.4 \pm 6.0$. The ratio of the $\mathrm{N}: \mathrm{P}$ in the $\mathrm{N}+\mathrm{P}$, which was 6.9 before amendment, decreased from 14.0 on Day 2 to 0.6 on Day 10, then increased to 3.2 before dropping again to 0.7 on the last day. The overall mean $\mathrm{N}: \mathrm{P}$ ratio in the $\mathrm{N}+\mathrm{P}$ was $5.7 \pm 5.2$.

Initial $\mathrm{Si}$ concentrations were $\sim 1 \mu \mathrm{mol} \mathrm{l}^{-1}$ in both mesocosms (Fig. 4B). In N+P, Si decreased to a minimum of $0.4 \mu \mathrm{mol} \mathrm{l}^{-1}$ over the first $10 \mathrm{~d}$, and then increased with the Phaeocystis pouchetii bloom to $1.6 \mu \mathrm{mol} \mathrm{l}{ }^{-1}$. On average, Si was significantly higher in the $\mathrm{N}+\mathrm{P}$ versus the $\mathrm{Ctrl}(\mathrm{p}<0.01)$. The ratio of DIN:Si was always $\leq 1.0$ in $\mathrm{Ctrl}$; addition of $\mathrm{NO}_{3}{ }^{-}$to the $\mathrm{N}+\mathrm{P}$ increased DIN:Si to 16.5 , but this decreased to 0.4 by Day 10 and remained at $<0.7$ thereafter.

\section{Specific nitrogen uptake}

Specific uptake rates are presented here for the $>35 \mu \mathrm{m}$ (i.e. Phaeocystis pouchetii colonies), FCM 


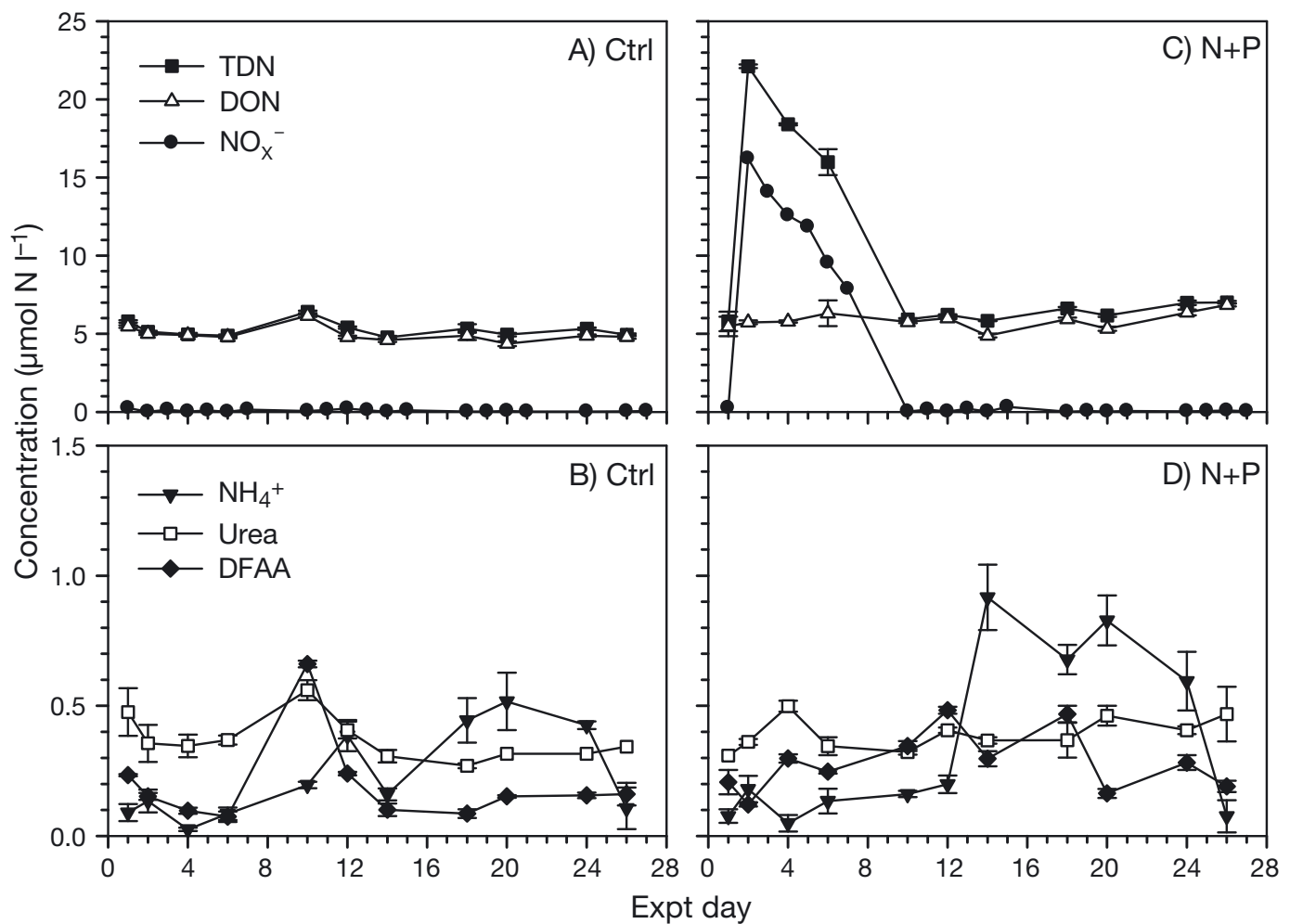

Fig. 3. Concentrations in the control $(\mathrm{Ctrl})$ and nutrient-amended $(\mathrm{N}+\mathrm{P})$ mesocosms of $(\mathrm{A}, \mathrm{C})$ total dissolved nitrogen $(\mathrm{TDN})$, dissolved organic nitrogen (DON), and nitrate + nitrite $\left(\mathrm{NO}_{\mathrm{X}}{ }^{-}\right.$), and $(\mathrm{B}, \mathrm{D}) \mathrm{NH}_{4}{ }^{+}$, urea, and dissolved free amino acids $(\mathrm{DFAA})$. Note the difference in $y$-axis scale between plots. Error bars (except $\left.\mathrm{NO}_{\mathrm{X}}{ }^{-}\right): \pm 1 \mathrm{SD}$ of the mean $(\mathrm{n}=2-3$; may be smaller than the symbols)

(<35 $\mu \mathrm{m}$ phytoplankton), and 0.2-0.8 $\mu \mathrm{m}$ (i.e. bacterial) fractions in order to compare $\mathrm{N}$ uptake by these different plankton constituents, both within and between mesocosms. In the Ctrl, specific uptake of $\mathrm{NH}_{4}^{+}$ and urea was not statistically different between the FCM and 0.2-0.8 $\mu \mathrm{m}$ fractions $\left(\mathrm{NH}_{4}{ }^{+}: \mathrm{p}=0.496\right.$; urea: $\mathrm{p}$ $=0.890$; Fig. 5A,C). In fact, bacterial urea uptake was relatively high over the final $2 \mathrm{wk}$ of the study. In contrast, $\mathrm{NO}_{3}{ }^{-}$uptake by the $\mathrm{FCM}$ fraction was twice that of the $0.2-0.8 \mu \mathrm{m}$ fraction $(\mathrm{p}=0.051)$, although uptake by these 2 converged over time (Fig. 5B). Specific

Table 1. Percent contribution of $\mathrm{NH}_{4}{ }^{+}, \mathrm{NO}_{3}{ }^{-}$, urea, dissolved free amino acids (DFAA), and bulk dissolved organic nitrogen (DON) to total dissolved nitrogen concentrations. Ctrl: unamended mesocosm; N+P: mesocosm fertilized with $\mathrm{NO}_{3}{ }^{-}$and $\mathrm{PO}_{4}{ }^{3-}$. Values: mean $\pm 1 \mathrm{SD}$ and (min.-max.) for 11 sampling days over a $26 \mathrm{~d}$ period

\begin{tabular}{|lccccc|}
\hline Mesocosm & $\mathrm{NH}_{4}{ }^{+}$ & $\mathrm{NO}_{3}{ }^{-}$ & Urea & DFAA & DON \\
\hline $\mathrm{Ctrl}$ & $4 \pm 3$ & $1 \pm 1$ & $7 \pm 1$ & $3 \pm 2$ & $94 \pm 4$ \\
& $(1-10)$ & $(0-4)$ & $(5-9)$ & $(2-10)$ & $(88-99)$ \\
$\mathrm{N}+\mathrm{P}$ & $5 \pm 6$ & $19 \pm 31$ & $5 \pm 2$ & $4 \pm 2$ & $76 \pm 28$ \\
& $(0-16)$ & $(0-73)$ & $(2-7)$ & $(1-8)$ & $(26-98)$ \\
\hline
\end{tabular}

DFAA uptake by the $0.2-0.8 \mu \mathrm{m}$ fraction in the Ctrl was significantly higher than by the FCM fraction throughout the study ( $\mathrm{p}<0.0001$; Fig. 5D).

It is important to note that specific uptake rates in the $>35 \mu \mathrm{m}$ fraction were negligible in the Ctrl due to the absence of colonial Phaeocystis pouchetii. Similarly, $\mathrm{N}$ uptake by the $>35 \mu \mathrm{m}$ fraction in the $\mathrm{N}+\mathrm{P}$ was low during the week preceding the colonial bloom (Fig. 5E-H). Specific uptake of $\mathrm{NO}_{3}{ }^{-}$and urea by the FCM fraction in the $\mathrm{N}+\mathrm{P}$ declined after 1 wk as $P$. pouchetii was increasingly retained by the $35 \mu \mathrm{m}$ mesh (Fig. 5F-G). However, uptake of $\mathrm{NH}_{4}{ }^{+}$and DFAA by the FCM fraction was not similarly affected by the removal of $P$. pouchetii colonies to the $>35 \mu \mathrm{m}$ fraction (Fig. 5E,H). In the $\mathrm{N}+\mathrm{P}$, specific uptake rates of $\mathrm{NH}_{4}{ }^{+}$, $\mathrm{NO}_{3}{ }^{-}$, and urea were about equal between the FCM and 0.2-0.8 $\mu \mathrm{m}$ fractions. After bloom initiation ( Day 8$)$, $\mathrm{N}$ uptake by the $>35 \mu \mathrm{m}$ fraction was significantly higher than that of the bacterial size class for $\mathrm{NH}_{4}{ }^{+}$( $\mathrm{p}<$ $0.05), \mathrm{NO}_{3}^{-}(\mathrm{p}<0.001)$, and urea $(\mathrm{p}<$ 0.0001). In contrast, DFAA uptake 

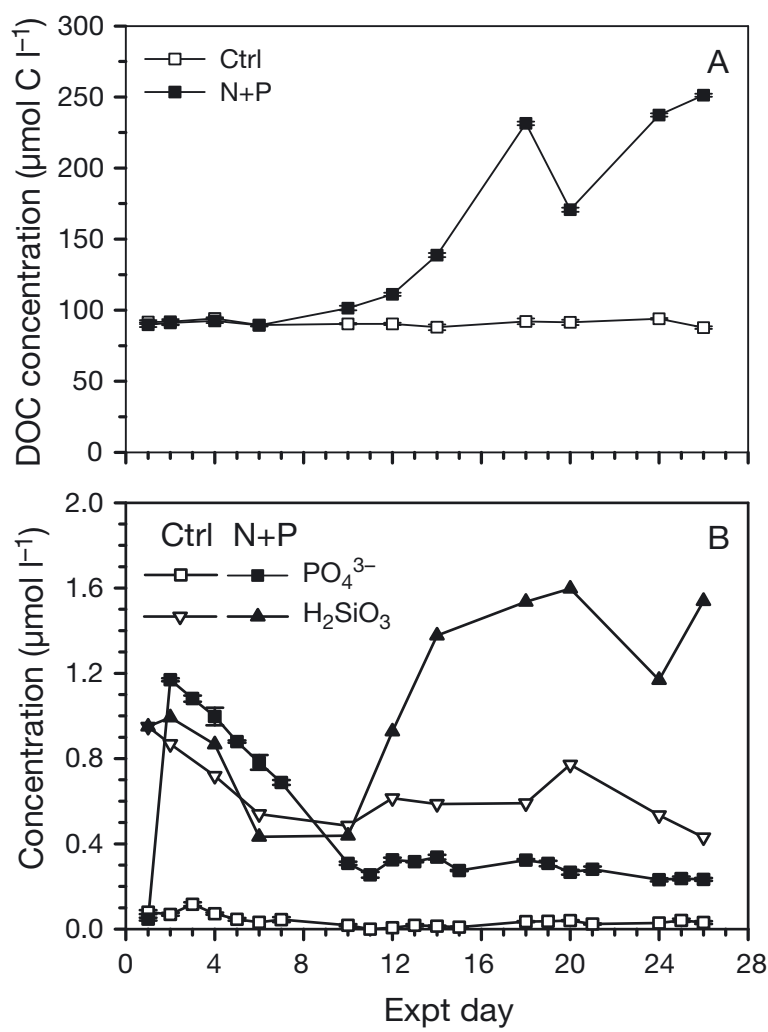

Fig. 4. Concentrations of (A) dissolved organic carbon (DOC), and (B) $\mathrm{PO}_{4}{ }^{3-}$ and silicic acid $\left(\mathrm{H}_{2} \mathrm{SiO}_{3}\right)$ in the control (Ctrl; open symbols) and nutrient-amended (N+P; filled symbols) mesocosms. Error bars (except $\mathrm{H}_{2} \mathrm{SiO}_{3}$ ): $\pm 1 \mathrm{SD}$ of the mean $(n=2-3)$

rates were higher in the $0.2-0.8 \mu \mathrm{m}$ fraction than the FCM $(p<0.01)$ or $>35 \mu \mathrm{m}(\mathrm{p}<0.05)$ fractions, despite a six-fold increase in the latter over the final week of the study (Fig. 5H).

Overall, specific uptake rates were similar in magnitude between mesocosms (Fig. 5), although amending $\mathrm{N}+\mathrm{P}$ resulted in significantly higher $\mathrm{NO}_{3}{ }^{-}$uptake by the $>0.8 \mu \mathrm{m}$ fraction ( $\mathrm{p}<0.05$; data not shown) and lower urea uptake $(\mathrm{p}<0.05)$ by the $0.2-0.8 \mu \mathrm{m}$ fraction, relative to the Ctrl. In the $\mathrm{N}+\mathrm{P}$ there was also a strong correlation between $\mathrm{NH}_{4}{ }^{+}$concentrations and specific $\mathrm{NH}_{4}{ }^{+}$uptake by the $>35 \mu \mathrm{m}\left(\mathrm{p}<0.0001, \mathrm{r}^{2}=\right.$ $0.87)$ and FCM $\left(p<0.0001, r^{2}=0.86\right)$ fractions.

\section{Absolute nitrogen uptake}

In contrast with specific uptake, absolute uptake rates in the $>35 \mu \mathrm{m}$ and FCM $(<35 \mu \mathrm{m})$ fractions were combined to compare $\mathrm{N}$ uptake by all autotrophs (Phyto) with that of the mixed assemblage retained on $0.8 \mu \mathrm{m}$ filters (Table 2) and that of bacteria (Fig. 6, Table 3). Nitrogen uptake by the $>0.8 \mu \mathrm{m}$ fraction, as with uptake measured using GF/F filters, is typically attributed to phytoplankton despite a presumed, but largely unknown, influence of bacteria. Although absolute uptake rate profiles were generally similar for these 2 fractions (data not shown), uptake by the $>0.8 \mu \mathrm{m}$ fraction was $2-$ to 5-fold higher in the Ctrl and up to 2-fold higher in the $\mathrm{N}+\mathrm{P}$, than in the respective Phyto fractions (Table 2).

Absolute uptake rates were also calculated for the total bacterial community (Bact) to account for $\mathrm{N}$ uptake by bacteria retained on $0.8 \mu \mathrm{m}$ filters. These rates were derived using specific uptake rates in the $0.2-0.8 \mu \mathrm{m}$ fraction, assuming they equal those of bacteria retained on $0.8 \mu \mathrm{m}$ filters, and total bacterial PN, which was calculated from the $0.2-0.8 \mu \mathrm{m}$ PN and bacterial retention on $0.8 \mu \mathrm{m}$ filters (see 'Materials and methods'). In the Ctrl, Phyto uptake of $\mathrm{NH}_{4}{ }^{+}, \mathrm{NO}_{3}{ }^{-}$, and urea generally exceeded that of Bact over the first $10 \mathrm{~d}$; thereafter, Bact uptake either equaled $\left(\mathrm{NH}_{4}{ }^{+}\right.$and $\mathrm{NO}_{3}{ }^{-}$) or exceeded (urea and DFAA) that of the Phyto fraction (Fig. 6A-D). Due to the higher phytoplankton biomass in $\mathrm{N}+\mathrm{P}$, absolute $\mathrm{N}$ uptake by Phyto dominated that of Bact for all substrates except DFAA. Uptake of DFAA by the Phyto fraction in $\mathrm{N}+\mathrm{P}$ increased exponentially during the last $2 \mathrm{wk}$, while rates in the Bact fraction generally decreased.

Although specific uptake rates were relatively similar between mesocosms, absolute $\mathrm{N}$ uptake by the Phyto fraction was, on average, 10- to 20-fold higher in the amended mesocosm, primarily as a result of greater biomass (Fig. 6E-H). In contrast, absolute $\mathrm{N}$ uptake by Bact was approximately equal between mesocosms for $\mathrm{NH}_{4}{ }^{+}(\mathrm{p}=0.211)$ and urea $(\mathrm{p}=0.936)$, but significantly higher in $\mathrm{N}+\mathrm{P}$ for $\mathrm{NO}_{3}{ }^{-}$and DFAA $(\mathrm{p}<$ 0.05 for both).

Overall, $\mathrm{NH}_{4}{ }^{+}$was the most important substrate to phytoplankton in the light mesocosms, contributing $>60 \%$ of total $\mathrm{N}$ uptake by the Phyto fraction (Fig. 7, Table 3). Nitrate and urea contributed about equally to

Table 2. Ratio of absolute uptake rates $\left(\rho\right.$ in $\mu$ mol $\left.\mathrm{N} \mathrm{l}^{-1} \mathrm{~h}^{-1}\right)$ in the $>0.8 \mu \mathrm{m}$ vs. phytoplankton-only (Phyto) fractions for $\mathrm{NH}_{4}{ }^{+}, \mathrm{NO}_{3}{ }^{-}$, urea, and dissolved free amino acids (DFAA) in the control (Ctrl) and amended $(\mathrm{N}+\mathrm{P})$ mesocosms. Mean $\pm \mathrm{SD}$ and (min.-max.) are given. ${ }^{*} \mathrm{p}<0.05 ;{ }^{* *} \mathrm{p}<0.01 ;{ }^{* * *} \mathrm{p}<0.001$ significance of the difference between $>0.8 \mu \mathrm{m}$ and Phyto absolute rates for each substrate and mesocosm. See Fig. 1 and 'Materials and methods' for a definition of Phyto

\begin{tabular}{|lccccc|}
\hline \multirow{2}{*}{ Mesocosm } & \multicolumn{4}{c}{$\rho(>0.8 \mu \mathrm{m}): \rho($ Phyto $)$} & \\
\cline { 3 - 5 } & $\mathrm{NH}_{4}^{+}$ & $\mathrm{NO}_{3}^{-}$ & Urea & DFAA \\
\hline Ctrl & $3.8 \pm 2.5$ & $2.1 \pm 0.6$ & $2.8 \pm 1.1$ & $4.8 \pm 4.8$ \\
& $(1.3-9.0)$ & $(1.1-3.4)$ & $(1.4-5.0)$ & $(1.4-17.6)$ \\
& & & ${ }^{* * *}$ & \\
$\mathrm{~N}+\mathrm{P}$ & $1.9 \pm 1.9$ & $1.4 \pm 0.5$ & $1.8 \pm 1.2$ & $2.0 \pm 1.0$ \\
& $(0.9-7.2)$ & $(1.0-2.6)$ & $(0.9-4.1)$ & $(1.1-4.1)$ \\
& & & & \\
\hline
\end{tabular}


Unamended (Ctrl)
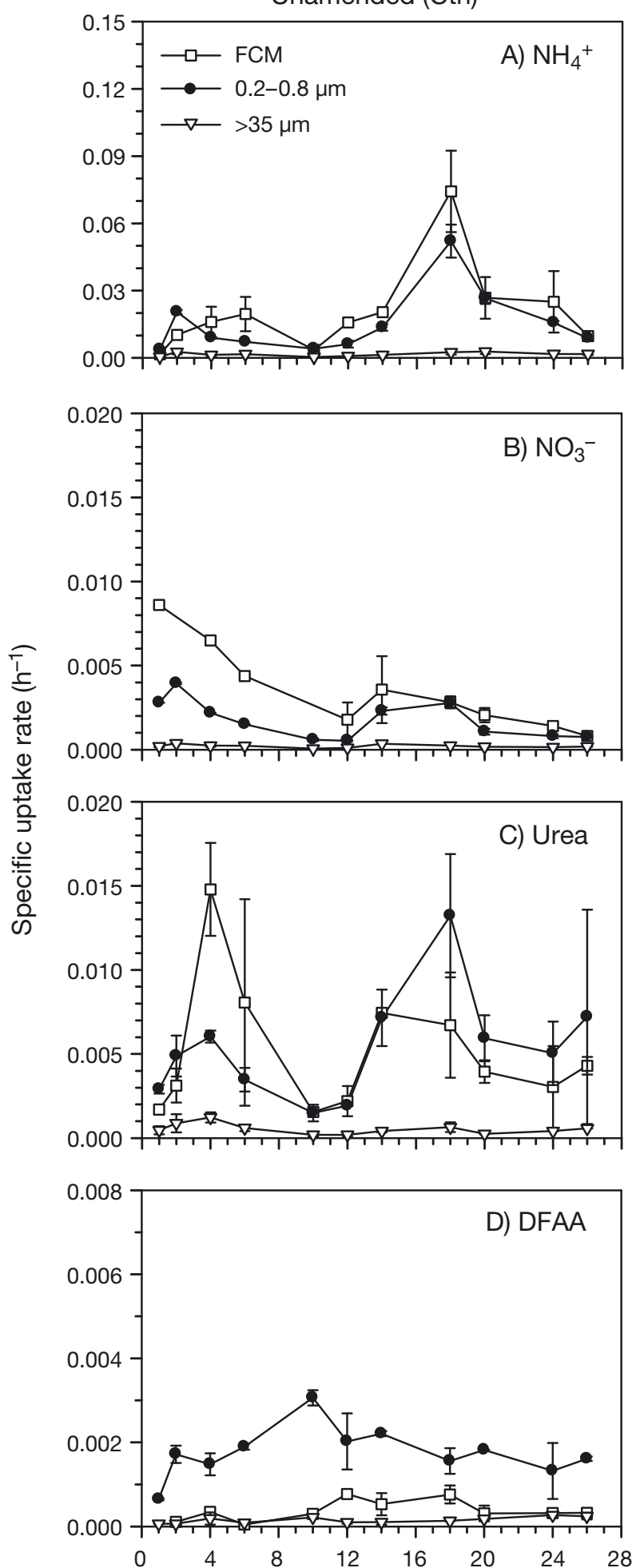

Fertilized $(\mathrm{N}+\mathrm{P})$
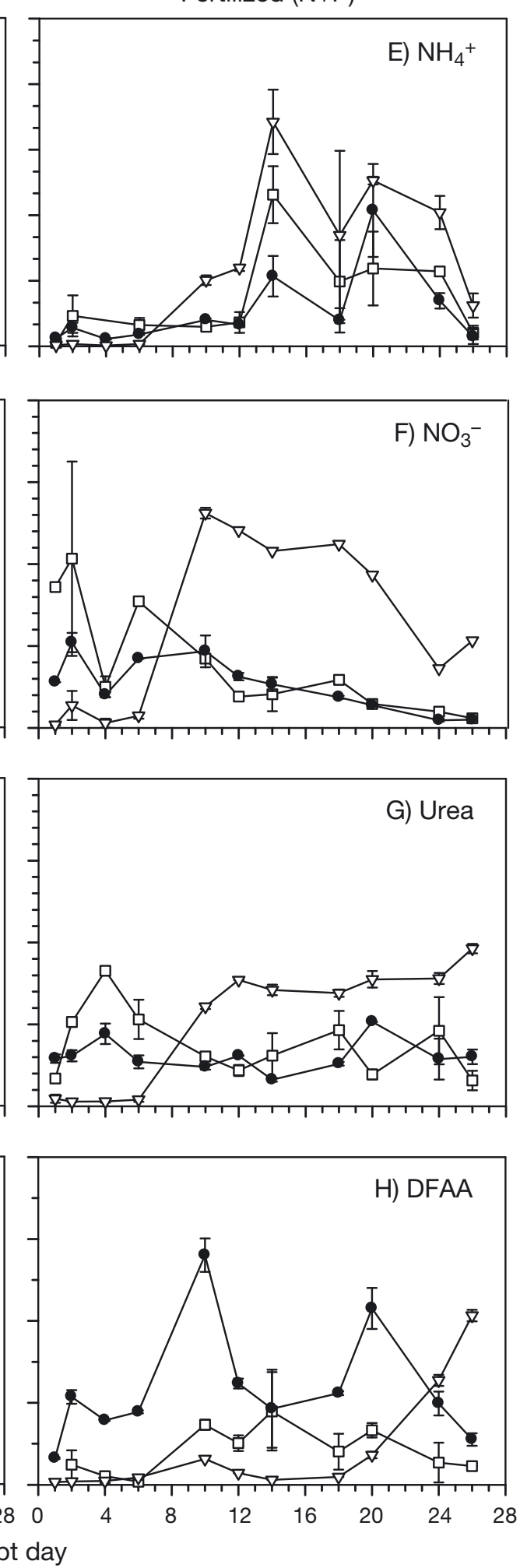

Fig. 5. Specific uptake rates of $\mathrm{NH}_{4}{ }^{+}, \mathrm{NO}_{3}{ }^{-}$, urea, and dissolved free amino acids (DFAA) by the $>35$ um (i.e. Phaeocystis pouchetii colonies), flow cytometer-sorted phytoplankton $<35 \mu \mathrm{m}(\mathrm{FCM})$, and $0.2-0.8 \mu \mathrm{m}$ (bacterial) fractions in the (A-D) control $(\mathrm{Ctrl})$ and $(\mathrm{E}-\mathrm{H})$ nutrient-amended $(\mathrm{N}+\mathrm{P})$ mesocosms. Error bars: $\pm 1 \mathrm{SD}$ of the mean (of duplicate incubations; may be smaller than the symbols) 
total $\mathrm{N}$ uptake in both enclosures, and DFAA were not a significant $\mathrm{N}$ source for phytoplankton. The contribution of $\mathrm{NO}_{3}{ }^{-}$to total $\mathrm{N}$ uptake by the Phyto fraction was negatively correlated with experiment day in both mesocosms (Ctrl: $\mathrm{p}<0.05, \mathrm{r}^{2}=0.48$; N+P: $\mathrm{p}<0.01$, $\left.\mathrm{r}^{2}=0.69\right)$. In contrast, $\mathrm{NH}_{4}{ }^{+}$comprised more of total uptake over time (Ctrl: $\mathrm{p}<0.05, \mathrm{r}^{2}=0.57$; $\mathrm{N}+\mathrm{P}$ : $\mathrm{p}<0.05$, $\left.r^{2}=0.48\right)$.
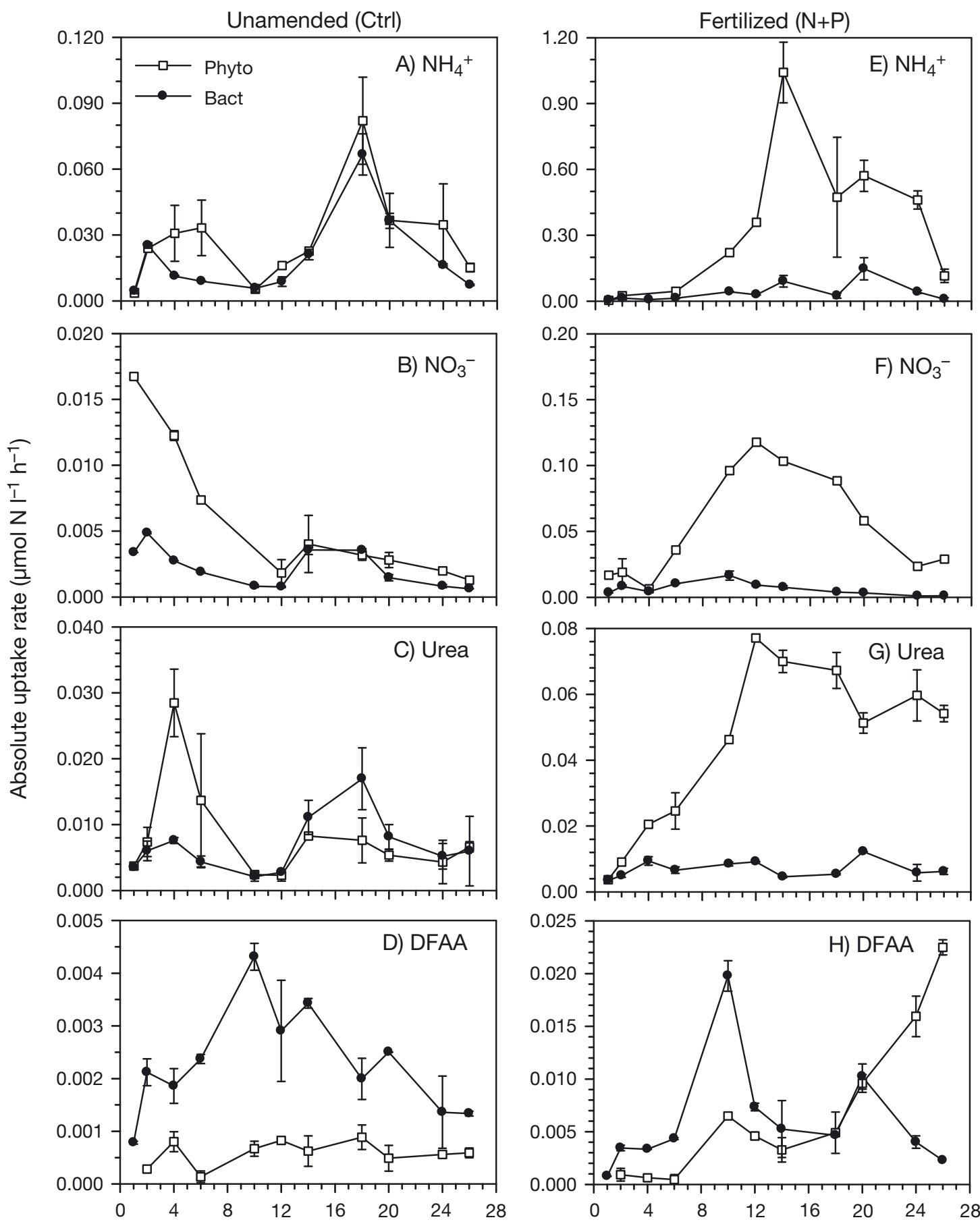

Expt day

Fig. 6. Absolute uptake rates of $\mathrm{NH}_{4}{ }^{+}, \mathrm{NO}_{3}{ }^{-}$, urea, and dissolved free amino acids (DFAA) by phytoplankton (Phyto) and total bacteria (Bact) in the (A-D) control (Ctrl) and $(\mathrm{E}-\mathrm{H})$ nutrient-amended $(\mathrm{N}+\mathrm{P})$ mesocosms. Phyto and Bact fractions are described further in the 'Results' and Fig. 1. Note the difference in $y$-axis scale between plots. Error bars: \pm 1 SD of the mean (of duplicate incubations; may be smaller than the symbols) 
Table 3. Percent contribution of each substrate to total measured $\mathrm{N}$ uptake by phytoplankton (Phyto) and bacteria (Bact). See Fig. 1 and 'Results' for description of Phyto and Bact. Bact/Total $(\%)=$ percent contribution of bact fraction to total uptake (Phyto + Bact) of each substrate. Values: mean \pm 1 SD and (min.-max.) for 11 sampling days over a $26 \mathrm{~d}$ period in the control (Ctrl) and amended $(\mathrm{N}+\mathrm{P})$ mesocosm

\begin{tabular}{|lcccc|}
\hline Mesocosm & $\mathrm{NH}_{4}{ }^{+}(\%)$ & $\mathrm{NO}_{3}{ }^{-}(\%)$ & Urea (\%) & DFAA (\%) \\
\hline Ctrl & & & & \\
$\quad$ Phyto & $64 \pm 23$ & $16 \pm 21$ & $19 \pm 10$ & $2 \pm 1$ \\
Bact & $57 \pm 13$ & $9 \pm 7$ & $24 \pm 8$ & $11 \pm 9$ \\
Bact/Total & $41 \pm 12$ & $31 \pm 12$ & $48 \pm 14$ & $79 \pm 9$ \\
& $(21-56)$ & $(17-53)$ & $(21-69)$ & $(69-95)$ \\
$\mathbf{N + P}$ & & & & \\
Phyto & $60 \pm 22$ & $23 \pm 20$ & $14 \pm 6$ & $2 \pm 3$ \\
Bact & $56 \pm 20$ & $14 \pm 10$ & $17 \pm 11$ & $12 \pm 5$ \\
Bact/Total & $19 \pm 16$ & $14 \pm 12$ & $20 \pm 14$ & $58 \pm 27$ \\
& $(5-56)$ & $(3-40)$ & $(6-49)$ & $(9-91)$ \\
& & & & \\
\hline
\end{tabular}

Bacteria also utilized more $\mathrm{NH}_{4}{ }^{+}$ than any other substrate in both mesocosms (Fig. 7, Table 3). The $0.2-0.8 \mu \mathrm{m}$ fraction in the $\mathrm{N}+\mathrm{P}$ relied slightly more on $\mathrm{NO}_{3}{ }^{-}$and slightly less on urea than in the Ctrl, but urea was the second most important $\mathrm{N}$ substrate (of those studied) to bacteria in both mesocosms. Compared to the Phyto fraction, Bact relied more on urea and DFAA, although the difference was significant for the latter only (Ctrl: $\mathrm{p}<$ 0.05; N+P: p < 0.001).

Ammonium regeneration rates in both mesocosms increased to a peak on Days 18 to 20, and were significantly higher in the $\mathrm{N}+\mathrm{P}(\mathrm{p}<0.05$; Fig. 8). Mean $\mathrm{NH}_{4}{ }^{+}$regeneration rates

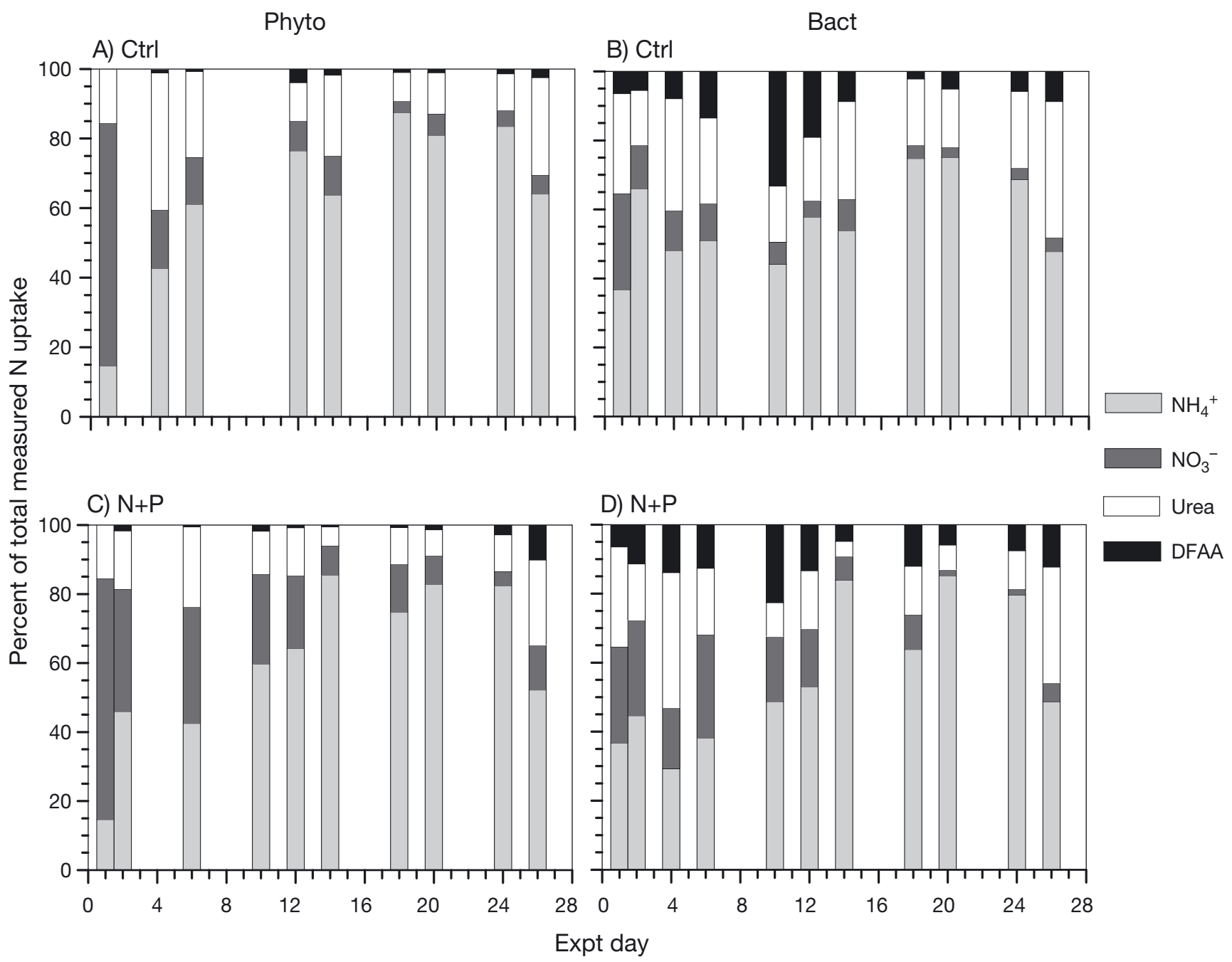

Fig. 7. Percent contribution of ${ }^{15} \mathrm{~N}$-labeled substrates to total measured $\mathrm{N}$ uptake by $(\mathrm{A}, \mathrm{C})$ phytoplankton (Phyto) and (B,D) total bacteria (Bact) in the $(\mathrm{A}, \mathrm{B})$ control $(\mathrm{Ctrl})$ and $(\mathrm{C}, \mathrm{D})$ nutrient-amended $(\mathrm{N}+\mathrm{P})$ mesocosms 


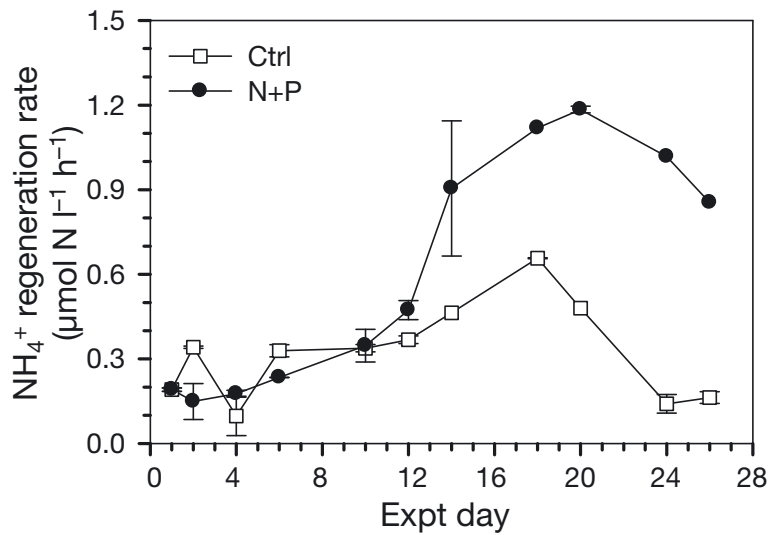

Fig. 8. Rates of $\mathrm{NH}_{4}{ }^{+}$regeneration in the control (Ctrl) and nutrient-amended $(\mathrm{N}+\mathrm{P})$ mesocosms. Error bars: $\pm 1 \mathrm{SD}$ of the mean (of duplicate incubations; may be smaller than the symbols)

were $0.324 \pm 0.169$ and $0.604 \pm 0.413 \mu \mathrm{mol} \mathrm{N} \mathrm{l}^{-1} \mathrm{~h}^{-1}$ in the $\mathrm{Ctrl}$ and the $\mathrm{N}+\mathrm{P}$, respectively. The relationship between ambient $\mathrm{NH}_{4}{ }^{+}$concentrations and $\mathrm{NH}_{4}^{+}$ regeneration rates was significant for the $\mathrm{N}+\mathrm{P}(\mathrm{p}<$ $0.01, \mathrm{r}^{2}=0.67$ ), but not for the Ctrl.

\section{DISCUSSION}

The ability of Phaeocystis spp. to maintain bloom density under varying nutrient regimes suggests that this alga may compete well against other phytoplankton, and potentially bacteria, for available $\mathrm{N}$ under both N-replete and N-limited conditions. We examined this phenomenon in mid-spring 2005 by inducing a bloom dominated by $P$. pouchetii using nutrientmanipulated mesocosms. Although the bloom only occurred when $\mathrm{NO}_{3}{ }^{-}$and $\mathrm{PO}_{4}{ }^{3-}$ were added, $\mathrm{NO}_{3}{ }^{-}$ dominated total $\mathrm{N}$ uptake on only 1 of 11 sampling days (Day 6). Overall, $\mathrm{NO}_{3}{ }^{-}$comprised as much of Phyto N use as did urea ( 20\%). Of the 4 substrates investigated in the present study, $\mathrm{NH}_{4}{ }^{+}$supplied the majority of $\mathrm{N}$ to Phyto and Bact (up to 88 and $85 \%$, respectively) in both mesocosms.

Based on initial DIN: $\mathrm{PO}_{4}{ }^{3-}$ ratios of $\sim 7$, phytoplankton in Raunefjord were apparently N- rather than Plimited prior to the start of this experiment. Relative to the Ctrl, fertilization resulted in significantly higher specific uptake of $\mathrm{NO}_{3}{ }^{-}$only, whereas an increase in the specific uptake of all $\mathrm{N}$ forms would have been expected if P-limitation was relieved by fertilization. Although phytoplankton were apparently N-limited before amendment, rapid removal of added $\mathrm{PO}_{4}{ }^{3-}$ highlights the importance of this nutrient to the Phaeocystis pouchetii bloom in $\mathrm{N}+\mathrm{P}$.

A similar study was conducted at the same location in 2003 (Nejstgaard et al. 2006, Sanderson et al. 2008).
Although nutrient amendment resulted in Phaeocystis pouchetii blooms in both studies, the uptake rate results were distinct. The most substantial difference between these 2 studies is that the 2003 experiment began on 28 February (vs. 1 April here), and therefore captured different ecosystem dynamics. In 2003, Si and $\mathrm{NO}_{3}{ }^{-}$were still relatively abundant on Day 1 of the experiment, and the typical diatom-Phaeocystis succession was observed. Depletion of $\mathrm{Si}$ and $\mathrm{NO}_{3}{ }^{-}$, which are crucial to diatom dominance, in the fjord prior to initiating the present study probably explains the absence of a diatom bloom in any of the mesocosms.

Sanderson et al. (2008) reported that urea dominated uptake by the $>0.8 \mu \mathrm{m}$ fraction during the induced Phaeocystis pouchetii bloom, likely a result of increased urea availability following the decline of the early diatom and flagellate bloom. In 2005, however, $\mathrm{NH}_{4}{ }^{+}$was the dominant $\mathrm{N}$ form used during the $P$. pouchetii bloom, perhaps also due to increased supply by regeneration. The increase in urea concentrations in 2003, but not in 2005, may have resulted from excretion by grazers feeding on diatoms and flagellates, which were relatively more abundant in the former study (Sanderson et al. 2008). In contrast, regeneration of $\mathrm{NH}_{4}{ }^{+}$during the 2005 bloom suggests that energy was transferred indirectly through the microbial loop rather than directly to zooplankton. Together, results from these 2 studies demonstrate that although $\mathrm{NO}_{3}{ }^{-}$is key to initiating Phaeocystis blooms, reduced $\mathrm{N}$ forms play an important role in sustaining the bloom once $\mathrm{NO}_{3}{ }^{-}$has been depleted. They also illustrate the versatility of Phaeocystis with respect to its ability to exploit various $\mathrm{N}$ sources as they become available.

\section{Phytoplankton nitrogen nutrition: ammonium versus nitrate}

Dominance of $\mathrm{NH}_{4}{ }^{+}$uptake, even after addition of $\mathrm{NO}_{3}{ }^{-}$, was unexpected based on results from the 2003 study, in which urea replaced $\mathrm{NO}_{3}{ }^{-}$as the dominant $\mathrm{N}$ form used during an induced Phaeocystis pouchetii bloom (Sanderson et al. 2008). However, the importance of $\mathrm{NH}_{4}{ }^{+}$over other $\mathrm{N}$ forms has been reported elsewhere. For example, in a mesocosm study conducted in Danish coastal waters during late spring, Joint et al. (2002) reported greater $\mathrm{NH}_{4}{ }^{+}$uptake relative to $\mathrm{NO}_{3}{ }^{-}$, despite fertilizing with $\mathrm{NO}_{3}^{-}$. Similarly, Smith (1993) found an inverse relationship between uptake of $\mathrm{NH}_{4}{ }^{+}$ and $\mathrm{NO}_{3}^{-}$during a spring bloom dominated by $P$. pouchetii in the Greenland Sea, with $\mathrm{NH}_{4}{ }^{+}$uptake exceeding that of $\mathrm{NO}_{3}{ }^{-}$in May. One explanation is that the phytoplankton community in Raunefjord, including solitary P. pouchetii cells, was adapted to low $\mathrm{N}$ availability following depletion of ambient $\mathrm{NO}_{3}{ }^{-}$earlier in the spring, 
and as such, could use regenerated $\mathrm{NH}_{4}{ }^{+}$more efficiently than added $\mathrm{NO}_{3}{ }^{-}$. Inhibition of autotrophic $\mathrm{NO}_{3}^{-}$ uptake by ambient $\mathrm{NH}_{4}{ }^{+}$is another potential explanation for the higher $\mathrm{NH}_{4}{ }^{+}$uptake rates (Dortch 1990, Cochlan $\&$ Bronk 2003). However, this was clearly not the case in the $\mathrm{N}+\mathrm{P}$, where added $\mathrm{NO}_{3}{ }^{-}$was quickly removed, and there was no significant relationship between specific $\mathrm{NO}_{3}{ }^{-}$uptake rates and ambient $\mathrm{NH}_{4}{ }^{+}$concentrations in the Ctrl $\left(\mathrm{p}=0.065, \mathrm{r}^{2}=0.33\right)$. Therefore, autotrophic preference for $\mathrm{NH}_{4}{ }^{+}$, rather than inhibition of $\mathrm{NO}_{3}{ }^{-}$use, seems likely.

Results from the Ctrl resembled ecosystem dynamics that might be expected for North Sea coastal waters in late spring, with a decreasing importance of $\mathrm{NO}_{3}{ }^{-}$to phytoplankton $\mathrm{N}$ nutrition concurrent with decreasing biomass and an increased dependence on $\mathrm{NH}_{4}{ }^{+}$. From a broader perspective, these results mimic the transition that characterizes most temperate marine ecosystems: a shift from new production (and diatom dominance) in spring to regenerated production (flagellates and Cyanobacteria) in summer.

Based on relationships between $\mathrm{NH}_{4}{ }^{+}$uptake, availability, and remineralization, $\mathrm{N}$ supply and demand processes appear to have been closely coupled in the nutrient-amended mesocosm. Elevated $\mathrm{NH}_{4}{ }^{+}$regeneration rates in this enclosure may have been due to bacterial remineralization of algal-exuded DON, sloppy feeding and excretion by grazers, or viral lysis. Grazermediated processes tend to be the dominant source of regenerated $\mathrm{NH}_{4}{ }^{+}$in marine ecosystems (Bronk \& Steinberg 2008). However, given the lack of DON accumulation with bloom decay in the $\mathrm{N}+\mathrm{P}$, as well as the predator defense mechanisms of colonial Phaeocystis pouchetii, such as its large size and general unpalatability (Nejstgaard et al. 2007), bacterial $\mathrm{NH}_{4}{ }^{+}$ remineralization may have been high. The profile of specific $\mathrm{NH}_{4}{ }^{+}$uptake by the $0.2-0.8 \mu \mathrm{m}$ fraction resembled that of the FCM and $>35 \mu \mathrm{m}$ fractions, which indicates that bacteria were also using regenerated $\mathrm{NH}_{4}{ }^{+}$. It is possible that one component of the bacterial community was remineralizing labile DON while another assemblage was complementing degradation of C-rich $P$. pouchetii exudates (e.g. mucopolysaccharides) with $\mathrm{NH}_{4}{ }^{+}$uptake.

\section{Phytoplankton versus bacterial nitrogen use}

Although the environmental factors that stimulate Phaeocystis spp. colony formation remain uncertain, it has been suggested that this process may be a strategic response to low nutrient availability that gives colonies a competitive advantage over other algae (Lancelot 1995). The dominance of $P$. pouchetii in the bloom described here demonstrates its competitive ability to ex- ploit both high $\mathrm{N}$ (e.g. added $\mathrm{NO}_{3}{ }^{-}$) and low $\mathrm{N}$ (e.g. after Day 10) conditions. The respective roles that P. pouchetii colonies versus solitary flagellate cells played in this outcome, however, are unclear. Relatively high specific $\mathrm{NH}_{4}{ }^{+}$uptake by the FCM fraction in the $\mathrm{N}+\mathrm{P}$ versus the sharp decline in $\mathrm{FCM} \mathrm{NO}_{3}{ }^{-}$uptake rates during colony formation suggest that colonies relied more on $\mathrm{NO}_{3}{ }^{-}$, whereas $\mathrm{NH}_{4}{ }^{+}$was more important to solitary cells (and other phytoplankton). Furthermore, the fact that specific $\mathrm{NH}_{4}^{+}$uptake rates of the FCM and $>35 \mu \mathrm{m}$ fractions were equal to or greater than those of the $0.2-0.8 \mu \mathrm{m}$ fraction in both mesocosms suggests that Phaeocystis pouchetii can compete well against heterotrophic bacteria for available $\mathrm{NH}_{4}{ }^{+}$.

Differences in $\mathrm{N}$ use by phytoplankton and bacteria are best demonstrated using absolute uptake rates calculated for the Phyto and Bact fractions (Fig. 6), which account for the bacterial biomass and activity captured on $0.8 \mu \mathrm{m}$ filters. Absolute uptake rates estimated for Bact were $\sim 40 \%$ higher than in the $0.2-0.8 \mu \mathrm{m}$ fraction in the Ctrl and $90 \%$ higher in the N+P. In the Ctrl, nutrient availability was limited and phytoplankton were initially better able to use available $\mathrm{N}$ than bacteria (except for DFAA). About halfway through the experiment, however, phytoplankton could no longer outcompete bacteria for available DIN, and bacterial uptake of urea and DFAA exceeded that of phytoplankton. Differences between phytoplankton and bacterial uptake of $\mathrm{NH}_{4}{ }^{+}, \mathrm{NO}_{3}{ }^{-}$, and urea in $\mathrm{N}+\mathrm{P}$ indicate that phytoplankton, especially Phaeocystis pouchetii, can exploit new $\mathrm{N}$ sources to form large blooms, but can also persist on regenerated $\mathrm{N}$ once $\mathrm{NO}_{3}{ }^{-}$has been exhausted. The results from the $\mathrm{N}+\mathrm{P}$ further suggest that the availability of bloom-derived organic $\mathrm{N}$ may have relieved bacteria from the need to compete with phytoplankton for limited $\mathrm{N}$ resources.

Bacterial uptake comprised a substantial portion of total uptake of all $\mathrm{N}$ forms in the Ctrl (Table 3). Urea is typically disregarded as an important $\mathrm{N}$ source to bacteria (Kirchman 2000), although several studies have found otherwise (Jørgensen 2006, Sanderson et al. 2008, Bradley et al. 2010b). In the present study, bacterial uptake represented $\sim 50 \%$ of total urea uptake in the Ctrl. Lower bacterial contribution to total uptake in $\mathrm{N}+\mathrm{P}$ was primarily a result of high phytoplankton biomass, since specific uptake rates in the $0.2-0.8 \mu \mathrm{m}$ fraction were relatively high (Fig. 5). Overall, bacteria relied more on DFAA and less on $\mathrm{NO}_{3}{ }^{-}$when compared to phytoplankton, which is not surprising given that bacteria tend to prefer DFAA over $\mathrm{NO}_{3}{ }^{-}$in marine environments (Kirchman 2000) and Phaeocystis competes well for $\mathrm{NO}_{3}{ }^{-}$under N-limited conditions (Riegman et al. 1992). However, a rapid increase in DFAA uptake by the $>35 \mu \mathrm{m}$ fraction was measured in the $\mathrm{N}+\mathrm{P}$ during the last week of the experiment (Fig. $5 \mathrm{H}$ ). 
Although prymnesiophytes, such as Phaeocystis, are known to use DFAA via extracellular enzymatic processes (e.g. Palenik \& Morel 1990, Berman \& Bronk 2003), the increase in DFAA uptake may also be due to the elevated activity of heterotrophic bacteria attached to senescent $P$. pouchetii colonies.

\section{Size-fractionated versus FCM-sorted nitrogen uptake}

To date, studies of phytoplankton $\mathrm{N}$ use have typically relied on filtration as a means of distinguishing autotrophic from heterotrophic activity, despite the size overlap between these groups and clogging effects on filters. These drawbacks have been demonstrated (Lee \& Fuhrman 1987, Gasol \& Morán 1999) but are often overlooked, and uptake rates measured on GF/F filters (nominal pore size of $0.7 \mu \mathrm{m}$ ) are generally attributed to phytoplankton. In the present study, FCM sorting was used not only to measure phytoplankton uptake without the confounding effect of bacteria, but also to examine how traditional filtration can lead to overestimation of phytoplankton $\mathrm{N}$ uptake.

Differences between absolute uptake rates in the $>0.8 \mu \mathrm{m}$ and Phyto (FCM $+>35 \mu \mathrm{m}$ ) fractions were hypothesized to be greatest in the $\mathrm{N}+\mathrm{P}$ as a result of high biomass and increased clogging effects on $0.8 \mu \mathrm{m}$ filters. However, absolute uptake rates in the $>0.8 \mu \mathrm{m}$ and Phyto fractions were not statistically different in the amended mesocosm, although these results are somewhat complicated by the fact that the $>35 \mu \mathrm{m}$ fraction represented over half the Phyto biomass, which is uncommon for most systems. In the Ctrl, on the other hand, uptake rates in the $>0.8 \mu \mathrm{m}$ fraction significantly exceeded those of the Phyto fraction for all substrates but $\mathrm{NO}_{3}{ }^{-}$(Table 2). There are 2, nonmutually exclusive ways in which bacterial retention on $0.8 \mu \mathrm{m}$ silver filters could have caused overestimation of absolute phytoplankton $\mathrm{N}$ uptake rates: (1) if bacteria were relatively more enriched in ${ }^{15} \mathrm{~N}$ than phytoplankton (i.e. used more substrate), and (2) overestimating phytoplankton PN due to retention of bacterial biomass. Evidence for the former should appear in the specific uptake rates. The only substrate for which $>0.8 \mu \mathrm{m}$ fraction specific rates significantly exceeded those of the FCM fraction was DFAA ( $p<$ 0.05), which is not surprising given bacterial affinity for this labile organic substrate. Nonetheless, this suggests that the contribution of bacterial biomass to $>0.8 \mu \mathrm{m}$ PN was the primary cause of higher uptake rates in this fraction relative to the FCM fraction in the $\mathrm{Ctrl}$. These results indicate that the use of $0.8 \mu \mathrm{m}$ filters (and presumably GF/F filters) may result in significant overestimation of phytoplankton $\mathrm{N}$ uptake.

\section{CONCLUSION}

Addition of $\mathrm{NO}_{3}{ }^{-}$and $\mathrm{PO}_{4}{ }^{3-}$ to $\mathrm{N}+\mathrm{P}$ resulted in a large bloom of Phaeocystis pouchetii, whereas no bloom occurred in the Ctrl. Although $\mathrm{NO}_{3}{ }^{-}$was clearly important to fueling the Phaeocystis pouchetii bloom, $\mathrm{NH}_{4}{ }^{+}$was the predominant form of $\mathrm{N}$ used by both phytoplankton and bacteria. Nitrate and urea each contributed roughly $20 \%$ to phytoplankton N uptake in both mesocosms. Amino acids, however, were a negligible $\mathrm{N}$ source to phytoplankton, but comprised $\sim 11 \%$ of total bacterial $N$ uptake. Overall, bacteria contributed significantly to total $\mathrm{N}$ uptake in the Ctrl, and although phytoplankton $\mathrm{N}$ uptake dominated that of bacteria in the $\mathrm{N}+\mathrm{P}, \mathrm{N}$ metabolism of these 2 groups was closely coupled.

Results from the Ctrl indicate that bacteria were able to compete effectively with phytoplankton for limited $\mathrm{N}$ resources. In the $\mathrm{N}+\mathrm{P}$, on the other hand, Phaeocystis pouchetii was able to exploit new $\mathrm{N}$ (i.e. added $\mathrm{NO}_{3}{ }^{-}$), rapidly form a colonial bloom, and then switch to regenerated $\mathrm{N}$ forms to sustain high biomass. Although previous studies of phytoplankton and bacterial $\mathrm{N}$ uptake have been hampered by methodological obstacles, the use of flow cytometric sorting of autotrophs in this study demonstrated how bacterial retention can lead to significant overestimation of phytoplankton $\mathrm{N}$ uptake in the $>0.8 \mu \mathrm{m}$ fraction, and underestimation of bacterial uptake in the $0.2-0.8 \mu \mathrm{m}$ fraction. The environmental conditions leading to the development of colonial Phaeocystis blooms versus diatom- or bacteria-dominated communities are undoubtedly complex, but accurate quantification of the $\mathrm{N}$ utilization patterns of these plankton groups will help clarify their ecological interactions.

Acknowledgements. We dedicate this paper to the legacy of Peter Verity. Peter touched countless individuals, both personally and professionally, and we celebrate his contributions to oceanographic research, science education, and public outreach. We are grateful to A. Aadnesen, H. Gjertsen, T. Sørlie, and the rest of the staff at the University of Bergen's Marine Biological Station, as well as Q. Roberts, J. Brofft, M. Booth, P. Simonelli, S. Putzeys, and T. Walters for their help in conducting this study. We also thank M. Hagebø for analyses of fixed nutrient samples, R. Condon and S. Baer for their assistance with DOC measurements, and I. Anderson and D. Steinberg for their comments on the manuscript. This research was supported by the US Department of Energy Biotechnology Investigations/Ocean Margins Program (FG02-98ER-62531 to D.A.B., M.E.F., and P.G.V.), the US National Science Foundation (OPP-00-83381 to M.E.F. and P.G.V., OCE-08-25999 to M.E.F., OCE-05-45312 to P.G.V., and OCE-07-52490 to D.A.B.), the Norwegian Research Council (152714/120 to J.C.N.), and the US Environmental Protection Agency (EPA) Science to Achieve Results (STAR) graduate fellowship program (FP916328 to P.B.B.). This publication is not officially endorsed by the US EPA and may not reflect the views of the agency. This paper is Contribution No. 3028 from the Virginia Institute of Marine Science, The College of William \& Mary. 


\section{LITERATURE CITED}

Berman T, Bronk DA (2003) Dissolved organic nitrogen: a dynamic participant in aquatic ecosystems. Aquat Microb Ecol 31:279-305

Bradley PB, Lomas MW, Bronk DA (2010a) Inorganic and organic nitrogen use by phytoplankton along Chesapeake Bay, measured using a flow cytometric sorting approach. Estuar Coasts 33:971-984

Bradley PB, Sanderson MP, Frischer ME, Brofft J, Booth MG, Kerkhof LJ, Bronk DA (2010b) Inorganic and organic nitrogen uptake by phytoplankton and heterotrophic bacteria in the stratified Mid-Atlantic Bight. Estuar Coast Shelf Sci 88:429-441

Bronk DA, Steinberg DK (2008) Nitrogen regeneration. In: Capone DG, Bronk DA, Mulholland MR, Carpenter EJ (eds) Nitrogen in the marine environment. Academic Press, New York, NY, p 385-467

Bronk DA, Lomas MW, Glibert PM, Schukert KJ, Sanderson MP (2000) Total dissolved nitrogen analysis: comparisons between the persulfate, UV and high temperature oxidation methods. Mar Chem 69:163-178

Bronk DA, See JH, Bradley P, Killberg L (2007) DON as a source of bioavailable nitrogen for phytoplankton. Biogeosciences 4:283-296

Brzezinski MA (1987) Colorimetric determination of nanomolar concentrations of ammonium in seawater using solvent extraction. Mar Chem 20:277-288

Cadée GC, Hegeman J (2002) Phytoplankton in the Marsdiep at the end of the 20th century; 30 years monitoring biomass, primary production, and Phaeocystis blooms. J Sea Res 48:97-110

Cochlan WP, Bronk DA (2003) Effects of ammonium on nitrate utilization in the Ross Sea, Antarctica: implications for $f$ ratio estimates. In: DiTullio GR, Dunbar RB (eds) Biogeochemistry of the Ross Sea, Vol 78. American Geophysical Union, Washington, DC, p 159-178

Conley DJ, Schelske CL, Stoermer EF (1993) Modification of the biogeochemical cycle of silica with eutrophication. Mar Ecol Prog Ser 101:179-192

$>$ Dortch Q (1990) The interaction between ammonium and nitrate uptake in phytoplankton. Mar Ecol Prog Ser 61: 183-201

Dugdale RC, Goering JJ (1967) Uptake of new and regenerated forms of nitrogen in primary productivity. Limnol Oceanogr 12:196-206

Dugdale RC, Wilkerson FP (1986) The use of ${ }^{15} \mathrm{~N}$ to measure nitrogen uptake in eutrophic oceans; experimental considerations. Limnol Oceanogr 31:673-689

Egge JK, Aksnes DL (1992) Silicate as regulating nutrient in phytoplankton competition. Mar Ecol Prog Ser 83:281-289

Erga SR, Heimdal BR (1984) Ecological studies on the phytoplankton of Korsfjorden, western Norway. The dynamics of a spring bloom seen in relation to hydrographical conditions and light regime. J Plankton Res 6:67-90

Gasol JM, Morán XAG (1999) Effects of filtration on bacterial activity and picoplankton community structure as assessed by flow cytometry. Aquat Microb Ecol 16:251-264

Gieskes WWC, Leterme SC, Peletier H, Edwards M, Reid PC (2007) Phaeocystis colony distribution in the North Atlantic Ocean since 1948, and interpretation of long-term changes in the Phaeocystis hotspot in the North Sea. Biogeochemistry 83:49-60

Glibert PM, Lipschultz F, McCarthy JJ, Altabet MA (1982) Isotope dilution models of uptake and remineralization of ammonium by marine plankton. Limnol Oceanogr 27: $639-650$
Hagebø M, Rey F (1984) Lagring av sjøvann til analyse av næringssalter. Fisken Havet 4:1-12 (English summary)

Hansell DA, Carlson CA, Bates NR, Poisson AP (1997) Horizontal export of organic matter in the Equatorial Pacific Ocean. Deep-Sea Res I 45:2115-2130

Humborg C, Conley DJ, Rahm L, Wulff F, Cociasu A, Ittekkot V (2000) Silicon retention in river basins: far-reaching effects on biogeochemistry and aquatic food webs in coastal marine environments. Ambio 29:45-50

Jacquet S, Havskum H, Thingstad TF, Vaulot D (2002) Effects of inorganic and organic nutrient addition on a coastal microbial community (Isefjord, Denmark). Mar Ecol Prog Ser 228:3-14

- Joint I, Henriksen P, Fonnes GA, Bourne D, Thingstad TF, Riemann B (2002) Competition for inorganic nutrients between phytoplankton and bacterioplankton in nutrient manipulated mesocosms. Aquat Microb Ecol 29:145-159

> Jørgensen NOG (2006) Uptake of urea by estuarine bacteria. Aquat Microb Ecol 42:227-242

Kirchman DL (2000) Uptake and regeneration of inorganic nutrients by marine heterotrophic bacteria. In: Kirchman DL (ed) Microbial ecology of the oceans. Wiley-Liss, New York, NY, p 261-288

Kirchman DL, Keil RG, Wheeler PA (1989) The effect of amino acids on ammonium utilization and regeneration by heterotrophic bacteria in the subarctic Pacific. Deep-Sea Res I 36:1763-1776

Koroleff F (1983) Determination of ammonium. In: Grasshof K, Ehrhardt M, Kremling F (eds) Methods of seawater analysis. Verlag Chemie, Weinheim, p 150-157

Lancelot C (1995) The mucilage phenomenon in the continental coastal waters of the North Sea. Sci Total Environ 165: 83-102

> Lancelot C, Mathot S (1987) Dynamics of a Phaeocystis-dominated spring bloom in Belgian coastal waters. 1. Phytoplankton activities and related parameters. Mar Ecol Prog Ser 37:239-248

Lee S, Fuhrman JA (1987) Relationships between biovolume and biomass of naturally derived marine bacterioplankton. Appl Environ Microbiol 53:1298-1303

Lipschultz F (1995) Nitrogen-specific uptake rates of marine phytoplankton isolated from natural populations of particles by flow cytometry. Mar Ecol Prog Ser 123:245-258

Nejstgaard JC, Frischer ME, Verity PG, Anderson JT and others (2006) Plankton development and trophic transfer in seawater enclosures with nutrients and Phaeocystis pouchetii added. Mar Ecol Prog Ser 321:99-121

> Nejstgaard JC, Tang KW, Steinke M, Dutz J, Koski M, Antajan E, Long JD (2007) Zooplankton grazing on Phaeocystis: a quantitative review and future challenges. Biogeochemistry 83:147-172

Oremland RS, Capone DG (1988) Use of specific inhibitors in biogeochemistry and microbial ecology. Adv Microb Ecol 10:285-383

> Palenik B, Morel FMM (1990) Comparison of cell-surface Lamino acid oxidases from several marine phytoplankton. Mar Ecol Prog Ser 59:195-201

Parsons TR, Maita Y, Lalli CM (1984) A manual of chemical and biological methods for seawater analysis. Pergamon Press, Oxford

Peperzak L, Colijn F, Gieskes WWC, Peeters JCH (1998) Development of the diatom-Phaeocystis spring bloom in the Dutch coastal zone of the North Sea: the silicon depletion versus the daily irradiance threshold hypothesis. J Plankton Res 20:517-537

> Price NM, Harrison PJ (1987) Comparison of methods for the analysis of dissolved urea in seawater. Mar Biol 94: 307-317 
Radach G, Berg J, Hagmeier E (1990) Long-term changes of the annual cycles of meteorological, hydrographic nutrient and phytoplankton time series at Helgoland and at LV Elbe 1 in the German Bight. Cont Shelf Res 10:305-328

Riegman R, Noordeloos AM, Cadée GC (1992) Phaeocystis blooms and eutrophication of the continental coastal zones of the North Sea. Mar Biol 112:479-484

Rivkin RB, Phinney DA, Yentsch CM (1986) Effects of flow cytometric analysis and cell sorting on photosynthetic carbon uptake by phytoplankton in cultures and from natural populations. Appl Environ Microbiol 52:935-938

Rodrigues RMNV, Williams PJIB (2002) Inorganic nitrogen assimilation by picoplankton and whole plankton in a coastal ecosystem. Limnol Oceanogr 47:1608-1616

Sanderson MP, Bronk DA, Nejstgaard JC, Verity PG, Sazhin $\mathrm{AF}$, Frischer ME (2008) Phytoplankton and bacterial uptake of inorganic and organic nitrogen during an induced bloom of Phaeocystis pouchetii. Aquat Microb Ecol 51:153-168

Sazhin AF, Artigas LF, Nejstgaard JC, Frischer ME (2007) The colonization of two Phaeocystis species (Prymnesiophyceae) by pennate diatoms and other protists: a significant contribution to colony biomass. Biogeochemistry 83:137-145

Selmer JS, Sörensson F (1986) New procedure for extraction of ammonium from natural waters for ${ }^{15} \mathrm{~N}$ isotopic ratio determinations. Appl Environ Microbiol 52:577-579

Sherr B, Sherr E, del Giorgio P (2001) Enumeration of total and highly active bacteria. In: Paul JH (ed) Marine

Editorial responsibility: Douglas Capone,

Los Angeles, California, USA microbiology, Vol 30. Academic Press, San Diego, CA, p $129-159$

Smith WO (1993) Nitrogen uptake and new production in the Greenland Sea: the spring Phaeocystis bloom. J Geophys Res 98:4681-4688

Townsend DW, Keller MD, Sieracki ME, Ackleson SG (1992) Spring phytoplankton blooms in the absence of vertical water column stratification. Nature 360:59-62

Tungaraza C, Rousseau V, Brion N, Lancelot C, Gichuki J, Baeyens W, Goeyens L (2003) Contrasting nitrogen uptake by diatom and Phaeocystis-dominated phytoplankton assemblages in the North Sea. J Exp Mar Biol Ecol 292:19-41

Valderrama JC (1995) Methods of nutrient analysis. In: Hallegraeff GM, Anderson DM, Cembella AD (eds) Manual on harmful marine microalgae, IOC Manuals and Guides No. 33. UNESCO, Paris, p 251-268

> Veuger B, Middelburg JJ, Boschker HTS, Nieuwenhuize J, van Rijswijk P, Rochelle-Newall EJ, Navarro N (2004) Microbial uptake of dissolved organic and inorganic nitrogen in Randers Fjord. Estuar Coast Shelf Sci 61: $507-515$

- Vrede K, Heldal M, Norland S, Bratbak G (2002) Elemental composition $(\mathrm{C}, \mathrm{N}, \mathrm{P})$ and cell volume of exponentially growing and nutrient-limited bacterioplankton. Appl Environ Microbiol 68:2965-2971

> Zubkov MV, Tarran GA (2005) Amino acid uptake of Prochlorococcus spp. in surface waters across the South Atlantic Subtropical Front. Aquat Microb Ecol 40:241-249

Submitted: February 5, 2009; Accepted: February 22, 2010 Proofs received from author(s): August 20, 2010 